Chapman University

Chapman University Digital Commons

War and Society (MA) Theses

Dissertations and Theses

Spring 5-6-2019

\title{
Denied to Serve: Gay Men and Women in the American Military and National Security in World War II and the Early Cold War
}

Gianni Barbera

Chapman University, barbe127@mail.chapman.edu

Follow this and additional works at: https://digitalcommons.chapman.edu/war_and_society_theses

Part of the Military History Commons, and the United States History Commons

\section{Recommended Citation}

Barbera, Gianni. Denied to Serve: Gay Men and Women in the American Military and National Security in World War II and the Early Cold War. 2019. Chapman University, MA Thesis. Chapman University Digital Commons, https://doi.org/10.36837/chapman.000058

This Thesis is brought to you for free and open access by the Dissertations and Theses at Chapman University Digital Commons. It has been accepted for inclusion in War and Society (MA) Theses by an authorized administrator of Chapman University Digital Commons. For more information, please contact laughtin@chapman.edu. 
Denied to Serve: Gay Men and Women in the American Military and National Security in World War II and the Early Cold War

A Thesis by

Gianni Barbera

\begin{abstract}
Chapman University
Orange, California

Wilkinson College of Arts, Humanities, and Social Sciences

Submitted in partial fulfillment of the requirements for the degree of

Master of Arts in War \& Society
\end{abstract}

May 2019

Committee in Charge

Gregory Daddis, Ph.D., Chair

Charissa Threat, Ph.D.

CK Magliola, MA 
The Thesis of Gianni Barbera is approved.

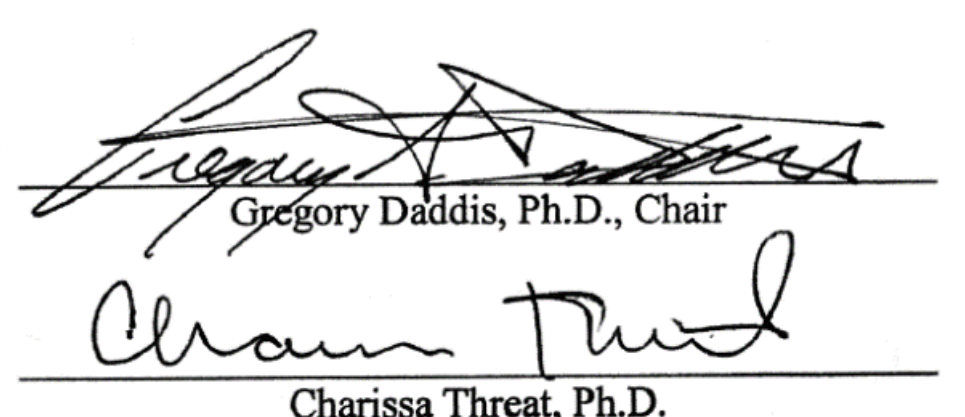

Charissa Threat, Ph.D.

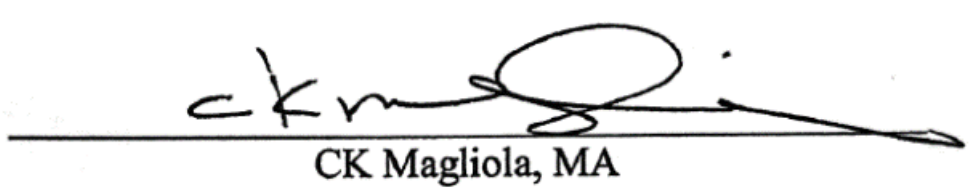

May 2019 
Denied to Serve: Gay Men and Women in the American Military and National Security in World War II and the Early Cold War

Copyright (C) 2019

by Gianni Barbera 


\begin{abstract}
Denied to Serve: Gay Men and Women in the American Military and National Security in World War II and the Early Cold War

by Gianni Barbera
\end{abstract}

Gay men and women have existed in the United States and in the armed forces much longer than legally and socially permitted. By World War II, a cultural shift began within the gay communities of the United States as thousands of gay men and women enlisted in the armed forces. Military policies barred gay service members by reinforcing stereotypes that gay men threatened the wellbeing of other soldiers. Such policies fostered the idea that only particular kinds of men could adequately serve. There were two opposing outcomes for the service of returning gay and lesbian veterans. For many hiding their sexuality from public view, they were granted benefits for their service to the country. For others not as lucky, they received nothing and were stripped of their benefits and rank. With the benefits of the new GI Bill, millions of veterans attended schools and bought homes immediately after the war, and the 1950s marked a new era in the course of the United States. But the Cold War's deep fear of communism and subversives gripped the United States at the highest levels of government and permeated to the rest of society.

This thesis examines the experiences of gay men and women in the American military in World War II and the early Cold War. Particularly after World War II, their experiences as veterans were not only limited to their time in service, but extended far into their civilian lives. This research primarily incorporates scholarly sources from 1981 to present with early gay magazines of the 1950s and 1960s and other archival materials available through the ONE National Gay \& Lesbian Archives at University of Southern California (USC) in Los Angeles. 


\section{TABLE OF CONTENTS}

Abstract iv

Introduction $\quad 1$

Chapter 1: The Early Communities 12

Chapter 2: Going to War 28

Chapter 3: Ending the Service of Gay Soldiers 51

Chapter 4: The Cold War $\quad 65$

$\begin{array}{ll}\text { Conclusion } & 93\end{array}$

$\begin{array}{ll}\text { Works Cited } & 99\end{array}$ 


\section{Introduction}

Edward was a local checkers champion in his youth, a National Guard veteran, and a successful accountant in Miami. Overshadowing each of his accomplishments, however was the fact that he loved other men. "I regret that I must ask you NOT TO PUBLISH the attached," Edward began his letter to a national magazine in 1960. "There are portions which may inevitably lead to me and cause me embarrassment or trouble."1 This letter was written to $O N E$, one of the earliest magazines specifically published for gay men and women. Published from 1953 to 1967, ONE was available in cities across the United States and through domestic and international mail. Edward had attached a ten-page biography to his letter that he sent to a contributor of $O N E$ magazine. His response was to another letter which appeared in the previous issue, with the hope that some part of his life story could be used to encourage a young gay veteran through a period of hopelessness, to "stop being sorry for himself," and "to live his own life.",

When Edward was a teenager, the boys with whom he had relationships taught him to play checkers at a competitive level to justify their frequent meetings. Among that group of friends was the first gay person he had ever met, a young man who eventually enlisted to fight in World War II, but then was killed. When Edward joined the National Guard, ${ }^{3}$ he was a court reporter for an early purge of officers and soldiers he knew, all accused of homosexual activities. Indeed, he himself was later accused of being gay, jailed, and dishonorably discharged. With his dishonorable discharge, he was prevented

\footnotetext{
${ }^{1}$ Craig M. Loftin, Letters to ONE: Gay and Lesbian Voices from the 1950s and 1960s (Ithaca, NY: State University of New York Press, 2014), 23. (Hereafter Letters to ONE)

${ }^{2}$ Letters to ONE, 22.

${ }^{3}$ In his letter, as to remain anonymous, Edward purposefully remained vague and provided few details when referring to locations in his past.
} 
from work in a government office, and worried that he could never start his own accounting firm, as a "scandal concerning my past history... might easily cause me to lose everything."4 Edward's description of his early adult life highlights the continued effects of the increasing pressure after World War II to remove gay men and women from the armed forces. Importantly, he intended his story to emotionally connect strangers like himself into some sense of a larger, hopefully national, community.

Building on Edward's story, this thesis argues that the World War II experience for gay men and women began a cultural shift in what people thought was possible for advancing civil rights to equality and social freedom within the gay community as the United States entered the Cold War. The cultural shift for gay Americans in the military during this period can be defined as a new sense of community and belonging, as well as a collective challenge to accepted beliefs that they were criminally deviant and incapable of military service. Yet, government and military practices excluded gay citizens from participation in the Cold War armed forces, before and after the McCarthy era and the Lavender Scare. They still continued to engage in national security issues, and in so doing, maintained social momentum in pursing civil rights. Military service historically served as an attestation of one's support of, and loyalty to, the United States, but military and government practices in this period were hostile towards gay Americans and prevented them demonstrating their good citizenship and patriotism. ${ }^{5}$ During the $1950 \mathrm{~s}$, organizations and publications like $O N E$ magazine were established to challenge anti-gay laws and rhetoric in a public space. These magazines not only provided a forum for gay

\footnotetext{
${ }^{4}$ Letters to ONE, 34.

${ }^{5}$ For more on how military service legitimized the naturalization of immigrants in the early twentieth century, see: Lucy E. Salyer, "Baptism by Fire: Race, Military Service, and U.S. Citizenship Policy, 19181935,” Journal of American History 91:3 (2004): 847-876.
} 
men and women to connect on a national level, but also provided historical insights into the fight for equality of gay Americans, where equality meant decriminalization of their sexuality and equal access to serve the nation through the military and government service during the Cold War era.

This thesis reveals some of these insights using primary sources such as letters, panel recordings, and the collection of ONE magazines available through the ONE National Gay \& Lesbian Archives at University of Southern California (USC). Within that archive are two collections this thesis will examine that belonged to World War II veterans. One collection concerns Henry Gerber, who authored an article in the September 1962 edition of $O N E .^{6}$ The other collection is of correspondence between Esther Herbert and Marvyl Doyle ${ }^{7}$, including love letters while in the Women's Army Corps (WAC). This paper also makes use of sources from $O N E$ 's audio archives that were products of $O N E$ 's regular seminar programs. ${ }^{8}$ The recording of a history seminar from 1978, for example, provides insight into the development of $O N E$ through personal experiences of the speakers and the history of individuals like Henry Gerber. Utilizing these sources, this thesis concentrates on the intersection of social and national security issues between 1940 and 1960 by using $O N E$ magazine with particular attention to articles dealing with gay veterans and their difficulties, memories, and viewpoints. Beyond the USC archives, the 1985 documentary Before Stonewall, directed by Greta Schiller and Robert Rosenberg, features interviews, footage, and commentary about the

\footnotetext{
${ }^{6}$ Henry Gerber, Henry Gerber Collection, (ONE Archives at USC Libraries, University of Southern, CA. Los Angeles, CA.) Coll2013-034. (Hereafter: Gerber Collection)

${ }^{7}$ Esther Herbert and Marvyl Doyle. Esther Herbert and Marvyl Doyle Papers and Photographs. (ONE Archives at USC Libraries, University of Southern, CA. Los Angeles, CA.) Coll2013-030. (Hereafter: Herbert and Doyle Collection)

${ }^{8}$ ONE Institute was the educational arm of ONE Inc. and continued to operate even after ONE Magazine discontinued. It published its own journal, held seminars, and issued a degree in homophile studies.
} 
gay community in the United States before and leading up to the Stonewall Riots. ${ }^{9}$ That film appears to have been ahead of many other scholarly works. This thesis also utilizes sourcebooks including My Country, My Right To Serve and Letters to ONE. Letters to $O N E$ is a sourcebook wherein Craig Loftin transcribed letters with little to no editorial commentary. ${ }^{10}$ Loftin's commentary is typically only a paragraph at the start of chapters. These chapters are divided by major themes, such as letters regarding personal relationships or letters about experiences with incarceration. My Country, My Right To Serve by Mary Ann Humphrey is a collection of oral histories collected by Humphrey with her own commentary limited to the start of each chapter, which are separated by conflict. ${ }^{11}$ Humphrey used her own experience of being forced to resign from the military in 1987 because of her sexual orientation, as the impetus to gather interviews and research that would educate Americans as to the contributions and experiences of gay service members. $^{12}$

Although World War II ended more than seventy years ago, scholarship regarding the contributions and experiences of gay soldiers came to fruition much later. Humphrey's My Country, My Right To Serve and Coming Out Under Fire by Allan Bérubé were both published in 1990. Both books served to expose an, until-then, unmentioned facet of American military history. Bérubé described his book as "one of

\footnotetext{
${ }^{9}$ The Stonewall Riots is the name given to a series of events that culminated in protests against police at the Stonewall Inn in New York. It is largely considered the spark that ignited the gay liberation movement. ${ }^{10}$ Letters to ONE.

${ }^{11}$ Mary Ann Humphrey, My Country, My Right to Serve: experiences of gay men and women in the military, World War II to the present (New York, NY: Harper Perennial, 1990). (Hereafter My Country My Right to Serve)

${ }^{12}$ Humphrey, My Country My Right to Serve, xiii.
} 
the first" to emerge from attempts by scholars of the gay community, starting in the 1970 s, to "uncover the history of ordinary gay men and women."13

Bérubé's book has remained a seminal work, alongside other cornerstone texts regarding gay military service. Leisa D. Meyer's Creating GI Jane, published in 1996, significantly expanded the scholarship regarding the role of women in the World War II military. Notably, she directly addressed Bérubé's analysis of tolerance in wartime towards lesbian soldiers and sought to expand understanding of that time in the greater context of women in World War II military service. ${ }^{14}$ The existence of a wartime lesbian subculture, Meyer showed, underscored the American public's concerns about women in a traditionally male role.

While Meyer described the 1940s as a time of transition, Margot Canaday has taken a more comprehensive approach in examining the slow, transitionary nature of U.S. government anti-gay legislation with her 2011 book The Straight State. Canaday dissects the connections between sexuality and American citizenship throughout the twentieth century by examining the development of immigration policy, military policy, and federal welfare programs in the decades after 1900. The Straight State examines the major transitions of the United States into the First World War, during the years of the Great Depression, and into World War II, as the United States increasingly focused on sexual, especially homosexual, identities parallel to its own development as a bureaucratic state. Canaday sought to complicate the notion that, due to the sudden and increased visibility of a gay subculture and community in World War II, the federal

\footnotetext{
${ }^{13}$ Allan Bérubé, Coming Out Under Fire: the history of gay men and women in World War Two (Chapel Hill, NC: The University of North Carolina Press, 2010), xvi.

${ }^{14}$ Leisa D. Meyer, Creating GI Jane: Sexuality and Power in the Women's Army Corps During World War II (New York, NY: Columbia University Press, 1996), 9.
} 
government sought to suppress sexual and gender non-conformity. ${ }^{15}$ Instead, Canaday argues, the government had policies that did not explicitly target homosexuality, but instead deviants, by controlling who received the benefits of citizenship and government assistance, and by creating an explicit homosexual-heterosexual binary after World War II. ${ }^{16}$ Laws and government policies, therefore, targeted homosexuality long before the Cold War.

William A. Taylor's Military Service and American Democracy (2016) is a more recent publication and addresses the numerous transitions of who could participate in the American military during the past century. Taylor argues that the policies of the United States military were in a constant state of flux as government and military officials determined "whether [service] was to be compulsory or voluntary, who served, and what was the best method of providing personnel for the nation's defense." ${ }^{17}$ He analyzes the debates over American military service from World War II into the present, including racial issues, the post-Cold War ban on homosexual activities in the military known as 'Don't Ask Don't Tell,' and the present state of military participation. Taylor shows that the limiting of military service repeatedly aroused similar arguments and restrictions to American notions of citizenship. Taylor does not place the debates over military participation for female troops before the late 1960s and gay troops before the 1990s, unlike Bérubé and Meyer. However he does provide contextual insights into the decisions and considerations by major policymakers in military times of transition.

\footnotetext{
${ }^{15}$ Margot Canaday, The Straight State: Sexuality and Citizenship in Twentieth-century America (Princeton, NJ: Princeton University Press, 2011), 2.

${ }^{16}$ Canaday, 3.

${ }^{17}$ William A. Taylor, Military Service and American Democracy: From World War II to the Iraq and Afghanistan Wars. (Lawrence, KS: University Press of Kansas, 2016), 3.
} 
Carolyn Herbst Lewis's Prescription for Heterosexuality (2010) further examines the enshrinement of a heterosexual society in the Cold War. Lewis uses the ways in which medical professionals positioned themselves to guard the sexual wellbeing of patients as a lens for viewing Cold War society. She directly connects the topics discussed by medical professionals in medical journals with the 'Red Scare' and the fear of communist infiltration and takeover. ${ }^{18}$ "Unhealthy"," "maladjusted," and "extramarital" sexual behavior were major concerns for doctors and linked to the threat of nuclear war because such activities were detrimental to the image of a strong American family ${ }^{19}$ In this way, homosexuality and the more public non-traditional behaviors of both gay and straight women in the United States were directly linked to public threats during the Cold War. Similar to Canaday's analysis of the government's rising influence in social affairs, Lewis explores the growth of the "awesome authority of the medical profession over the private lives of American citizens. ${ }^{, 20}$ Importantly, the development of the normative American family in the Cold War was an evolution of public participation in the national defense. ${ }^{21}$

The Lavender Scare (2004) by David K. Johnson ranks among the more prominent works on the persecution of gay government workers during the Cold War. The title of his book invokes the 'Red Scare' and transforms its target away from communism and toward homosexuality, much like how many Americans did. Johnson asserts that very little attention has been directed at the Cold War persecution of gay

\footnotetext{
${ }^{18}$ Carolyn Herbst Lewis, Prescription for Heterosexuality: Sexual Citizenship in the Cold War Era. (Chapel Hill, NC: University of North Carolina Press, 2010), 3.

${ }^{19}$ Lewis, 3.

${ }^{20}$ Lewis, 7.

${ }^{21}$ Elaine Tyler May, Homeward Bound: American families in the Cold War era (New York, NY: Basic Books, 2017). May's Homeward Bound also emphasized the role of "domestic containment," over the use of explicit military force, to contain the perceived threat of communism and other security threats.
} 
government workers in the name of national security, and that other studies "all but ignore how the fear of Communists and homosexuals overlap." 22 Johnson notes a contradiction that, while Senator McCarthy (R-WI) defined the Red Scare and even referenced threats from both "communists and queers," the purges of homosexuals in government happened beyond McCarthy’s own committees and therefore scholarship that focuses solely on McCarthy overlooks much of the Lavender Scare. ${ }^{23}$ His argument cautions against the idea that the Lavender Scare, and even the Red Scare, was limited only to the active years of the Wisconsin senator. ${ }^{24}$ Instead, McCarthy was a highly visible factor in the larger picture of the Cold War and postwar bureaucracy that sought to eliminate so-called "security risks" who were perceived by investigators and the public to exist in both the military and civilian spheres. ${ }^{25}$

Finally, Craig M. Loftin published Masked Voices in 2012, complementing the publication of his sourcebook Letters to ONE. Masked Voices is a social history of the early movements to establish a national gay community in Cold War America. Both texts are centered on the development of, and responses to, the magazine $O N E$, published in Los Angeles, the corporate archive of which is now located at USC. Loftin describes ONE magazine as a part of a much broader reexamination of American society in print media after World War II, as ONE preceded popular magazines like Confidential and Playboy by only one year. Also, Loftin notes that $O N E$ was influenced by the social justice and civil rights movements of the 1950 and 1960 s. $^{26}$ Loftin is wary of histories

\footnotetext{
${ }^{22}$ David K. Johnson, The Lavender Scare: the Cold War persecution of gays and lesbians in the federal government (Chicago, IL: University of Chicago Press, 2004), 2.

${ }^{23}$ Johnson, 3-4.

${ }^{24}$ Johnson, 4.

25 Johnson, 13.

${ }^{26}$ Craig M. Loftin, Masked Voices: gay men and lesbians in Cold War America (Albany, NY: State University of New York Press, 2012), 9.
} 
that focus on the "brave few" of the 1950s gay rights movements as they tend to give the appearance of a social consciousness limited to a select few rather than as the "tip of a much larger iceberg" of discontent and activism. ${ }^{27}$ When addressing Cold War anxiety and paranoia, Loftin names Johnson as one of the few historians of the McCarthy era to address McCarthy's impacts on the gay community. ${ }^{28}$ Whereas Taylor delved into the decisions of major policymakers like presidents and generals, and Lewis studied a class of professionals, Loftin's books are about “ordinary gay men and lesbians...caught between dissonant forces operating in American politics, culture, and sexuality."29

Most names of individuals referenced in scholarship are pseudonyms, as gay men and women across the United States faced legal and social consequences for being 'out' until relatively recently. Presently, a number of states in 2019 do not protect LGBTQ+ people from discrimination and this paper is sensitive to these issues. Authors like Loftin rightfully obscured the locations of letter writers and omitted major personal identifiers, especially if such a letter requested any future publication to do so. Some letters, like ones from Henry Gerber, were obviously by him and Gerber's name will be used because he published openly under his name and was written about in scholarship after his death. The collections from Esther Herbert and Marvyl Doyle included a personal history written by Herbert of herself, her partner, and her friends which indicates she intended for their letters to be accessible in a historical context. But most collections are not that way. As such, this paper makes no effort to identify specific individuals or where they lived

\footnotetext{
${ }^{27}$ Loftin, 5 .

${ }^{28}$ Loftin, 6 .

${ }^{29}$ Loftin, 2.
} 
and worked, beyond a general notion for context, and will use the names given in each respective source.

Over the past century, the terminology used to describe these communities and people has evolved. What is considered the LGBTQ+ community in 2019 is sometimes interchangeably used with the term LGBT, queer, or gay. The term homosexual sometimes has a different connotation than the word gay. Words like lesbian and gay are used somewhat interchangeably in public and in scholarship. While bisexuality, or the attraction to multiple genders, is a commonly accepted phrase today, in the 1950s that word had a different meaning and would still have been seen as someone who was not gay, but also as not-heterosexual in a legal sense. Because transgender activism was less public than gay activism before the 1970s, often individual accounts in these sources, about themselves and others, do not offer a distinction between drag performance, effeminate dress in men, masculine dress in women, and transgender men and women. These issues simply come down to the fact that the culture and laws of the United States during the Cold War era typically dealt in 'normal' and 'deviant,' the difference between a 'good' American citizen promoting a 'proper' lifestyle and someone who was not. As such, this thesis refers to non-heterosexual people and groups within as gay, though that is not to mean they could not have had other identities. Starting early in the twentieth century, the collective drive among gay men and women of the time to create a civil consciousness, to see themselves as a community and to be accepted in their greater social spheres, was known often known as the homophile movement. The push by the queer community to be treated with equality, to live openly without fear of violence or 
legal retaliation in their daily lives, is often called the 'gay rights movement' but even that title has evolved from other names and will continue to do so.

With the majority of scholarship into the experiences of gay soldiers in World War II written in the past three decades, and the ban on gay military service lifted only in 2011, any history of gay and lesbian military service in the United States seems to be a more specialized field of study. The time of gay activism and community formation known as the time 'before Stonewall,' before the transformational height of civil protest and counterculture in the Cold War era, is discussed in most all of these works. This thesis melds the early work of Bérubé with recent scholarship of Loftin and Johnson, with a focus on national security issues writ large, to better construct the interconnected and personal histories of gay and lesbian service members from the end of a worldwide war to a new, Cold War against internal and external threats, only to be labeled as that threat. Chapter 1 of this thesis describes the contentious social and legal relationship of the early gay community to the rest of the United States in the early twentieth century and examines an early attempt and gay rights organization. Chapter 2 and Chapter 3 examine the entrance of gay Americans into World War II alongside the rest of the country, how they met each other, and how they either benefited from their service or how the military removed them. Chapter 4 contextualizes the formation of early gay rights organizations and community against the backdrop of the social pressures of the Red Scare and the early Cold War. 


\section{Chapter 1: The Early Communities}

The gay communities of the United States did not suddenly appear during World

War II, but existed in more secretive and suppressed forms, often concentrated in large cities. During the 1920s and 1930s, German sexologists like Magnus Hirschfeld were known for their work to legalize the opportunity for men and women to wear clothes that were typically reserved for another gender. ${ }^{30}$ Hirschfeld traveled to many countries to present his research and publicly argued against the enforcement of anti-gay laws when sexual activity was between consenting adults. Weimar Germany became an international hub of such efforts. German organizations like the League for Human Rights (LHR) lamented that men and women "who love the same sex are derided and ridiculed by heterosexuals" because of their sexuality, and the LHR frequently called upon the gay communities in Berlin to organize, to combat, and to boycott businesses and social clubs that levied "injustice and humiliation" against gays. ${ }^{31}$

In Germany, establishments like theatres that catered to homosexual audiences did not publicly advertise until after World War I. ${ }^{32}$ Bars and clubs that did publicize dances and parties for gay clients were frequently suppressed by Berlin police until $1924 .{ }^{33}$ But by 1926 Hirschfeld began to see changes in Weimar-era Germany. Perhaps ironically, he credited the minimal enforcement of anti-gay laws within Berlin to the

\footnotetext{
${ }^{30}$ Before Stonewall: The Making of a Gay and Lesbian Community, Dir: Gretta Schiller and Robert Rosenberg, (New York, NY: Before Stonewall, Inc., 1985) Digital Film, 16:20. Sexology refers to the scientific study of human sexuality, a profession that was particularly known for studying sex and psychology in the early twentieth century.

${ }^{31}$ League for Human Rights, "Appeal to all Homosexual Women” in Anton Kaes, Martin Jay, and Edward Dimendberg, eds, The Weimar Republic Sourcebook (Berkley, CA: University of California Press, 1995), 704-705. (Hereafter: The Weimar Republic Sourcebook.)

${ }^{32}$ Laurence Senelick, "The Homosexual Theatre Movement in the Weimar Republic," Theatre Survey 49:1 (2008), 7.

${ }^{33}$ Senelick, 8 .
} 
police. Since homosexuality was natural, he argued, arresting all gay men and women (especially in high society) would have led to mass scandals. ${ }^{34}$

\section{Gay America}

Such changes, though not as perceptible, were occurring in America as well. Henry Gerber was an early example of the homophile movement in the 1920s within the United States, and in later years he often was involved with gay rights publications like ONE. Gerber was born in 1892 and emigrated from Germany to the United States in 1913. By 1920, he enlisted in the United States Army and was a part of the post-World War I occupation forces. While stationed in Germany, he took trips to Berlin where he subscribed to homophile magazines because, unlike in the United States, some Weimar Republic laws were more accepting of homosexual acts. ${ }^{35}$ Gerber recalled that "I had always bitterly felt the injustice with which my own American society accused the homosexual of 'immoral acts. ${ }^{{ }^{36}}$ Compared to the more-unified German laws in the 1920s, the United States "was in a contradiction of chaos and misunderstanding" in regards to legislation on homosexuality. ${ }^{37}$ As the threat of going to jail did not dissuade Gerber, while employed in a post office after returning from the Army, he began the work to establish a homophile organization in Illinois.

The American gay community of the early twentieth century was primarily situated in cities like Chicago, New York, New Orleans, Miami, San Francisco, and Los Angeles. Urban centers allowed for the concentration of people with similar desires and

\footnotetext{
${ }^{34}$ Magnus Hirschfeld, "Sexual Catastrophes," in The Weimar Republic Sourcebook, 700-701.

${ }^{35}$ Henry Gerber, "The Society for Human Rights," in ONE: The Homosexual Viewpoint 10:9 (September 1962), 5.

${ }^{36}$ Gerber, "The Society for Human Rights," 5.

${ }^{37}$ Gerber, "The Society for Human Rights," 6.
} 
leanings into enclaves much like the same cities had for ethnic minorities. Yet gay people were still relegated to relatively small communities within these much larger cities. ${ }^{38}$ While there were public political movements in Germany's Weimar Republic, and while American cities had bars that served gay and lesbian clientele, there was little organization for expanding civil rights within the American gay community. Harry Hay, who later founded the Mattachine Society, described there even being no word for gay people early on, just euphemisms like "temperamental" or others might say they were "in the life." ${ }^{39}$ Another person recalled "there were certain subjects one just didn't talk about. You just said... 'He's difficult.' Or 'The family is having problems with him.”, ${ }^{\text {, Among }}$ gay men and women not from large cities, experiences like "I thought I was the only one until I left home," or descriptions of childhood where "I was brought up on a farm, I knew enough not to talk about it, I knew enough to hide," were not outliers. ${ }^{41}$ At the same time, police records in New York frequently identified public parks and washrooms as locations where sex workers and men seeking sex, from both women and men, gathered due to the central nature of such locations within cities and yet their isolated and frequently dark nature at night. ${ }^{42}$ But, harassment, mental institutions, and other threats to safety were not uncommon experiences to gay Americans. One woman, Donna, recalled that her mother was told she was "living a lesbian life" with another woman and that

\footnotetext{
${ }^{38}$ Before Stonewall, 8:00. Michael Bronski, A Queer History of the United States (Boston, MA: Beacon Press, 2011), 112.

${ }^{39}$ Before Stonewall, 5:30.

${ }^{40}$ Charles Kaiser, The Gay Metropolis (New York, NY: Grove Press, 1997), 15.

${ }^{41}$ Before Stonewall, 2:00.

${ }^{42}$ George Chauncey, Gay New York: Gender, Urban Culture, and the Making of the Gay Male World (1890-1940) (New York, NY: Basic Books, 1994), 196.
} 
Donna's mother was able to immediately have her committed, without a hearing, to an insane asylum, directly from the street or apartment. ${ }^{43}$

Gay people in the 1920s and 30s would often try to identify each other by certain clothing choices or conversation topics. For example, seeing someone match the color of a handkerchief with a tie, that signalled "you figured you had a brother there." ${ }^{44}$ When Harry Hay was in high school, he learned of Pershing Square in Los Angeles. Pershing Square was a center of gay life in Los Angeles at the time. He had been told it was where "queers and faggots" would hang out, but when he investigated he took several weeks to meet any other gay men as he did not originally know the language used for cruising. ${ }^{45}$ Such coded language protected gay men in cities like Los Angeles and New York, as gay men faced particular danger when cruising in public places from anti-gay vigilantes and police. Plainclothes police officers regularly patrolled parks and bars in 1910 and onward, surveilling for suspect activities, as gay men were labeled as "male prostitutes" and subject to the attention of the vice squads in police departments. ${ }^{46}$ Though sodomy was a felony, the majority of gay men, when arrested, were charged with misdemeanors for disorderly conduct and "degeneracy," meaning that the cases officers made against homosexuals required significantly less evidence and did not lead to a trial by jury. ${ }^{47}$

The way in which homosexuality was frequently associated with vice and sex meant that police conflated gay relationships and interactions with prostitution. By 1923, a New York statute defined homosexuality as crimes where men "frequent or loiter about

${ }^{43}$ Before Stonewall, 5:00.

${ }^{44}$ Before Stonewall, 6:20.

${ }^{45}$ Joe Gilgamesh, Jim Kepner, Michael Lombardi, and Mikhail Itkin, “A search for our roots, 1860-1960," Midwinter Institute panel discussion, Los Angeles, CA, January 1978, ONE National Gay and Lesbian Archives, USC Digital Library.

${ }^{46}$ Chauncey, 185.

${ }^{47}$ Chauncey, 185. 
any public place soliciting men for the purpose of committing a crime against nature or other lewdness." 48 Harlem and Greenwich Village in New York were known for having "freer social norms" and were where speakeasies, along with a homosexual subculture, began to prosper underground. ${ }^{49}$ While most establishments in that time were not targeted at a gay clientele, gay men and women described the illegal and secretive nature of parties and clubs during prohibition as fostering an atmosphere of openness and exploration of life outside of social norms.

The repeal of prohibition in the mid-1930s, however, brought the underground nightlife of the 1920s into the public sphere again. New York and other metropolitan night life could now be legitimized by the state and legislated in such a way as to support a 'proper' public morality. Entrepreneurs sought to "reenter business and create sanitized forms of entertainment" and the repeal of prohibition redrew and emphasized the boundaries of "acceptable" and "unacceptable" public activity. ${ }^{50}$ Because so much of 1920s culture, and particularly metropolitan gay culture, revolved around bars, New York authorities refused to grant liquor licenses to establishments that showed an inability to prevent 'disorder.' Disorder, as it was defined, notably targeted the presence of gay men and women, sex workers, gamblers, and "undesirables" within the premises of a business.

Newspapers in the early 1930s publicly criticized clubs that featured drag or crossdressing performers, and masters of ceremony "who boast of a lavender tinge in their make-up," in other words, all establishments with visually gay clientele. ${ }^{51}$ Beyond

\footnotetext{
${ }^{48}$ Chauncey, 185. Chauncey also states that the statute was separate, yet incredibly similar, to the statute against female prostitution.

${ }^{49}$ Before Stonewall, 8:20.

${ }^{50}$ Chauncey, 337. Here, Chauncey cites arguments made by the historian Lewis Erenberg.

${ }^{51}$ Chauncey, 331. Before Stonewall, 10:20. One such example was provided by interviewees in Before Stonewall, who recalled Gladys Bentley, a female musician who always wore pants and a tuxedo, as an overt lesbian, along with other well-known performers in the same kinds of Harlem clubs.
} 
the bars and clubs there was another public push for censorship in Hollywood and film with the Hays Code, which regulated against showing "low forms of sex relationships" as commonplace, much less as acceptable. ${ }^{52}$ Like film industry regulation, state laws were deliberately vague and provided entities like New York's State Liquor Authority with broad control of licenses to enforce public morality, "lest the craft of man evade the definition" of the law. ${ }^{53}$ Police were in frequent communication with liquor authorities to close bars that served gay clients and police continued their public observation and arrests, forcing gay people out of public spaces. Bars that were forced to shut down in this way did attempt to fight the decisions of the Liquor Authority, but they were unsuccessful and legal authorities cemented the power of the state to prevent the service and public meeting of "lewd and destitute" people like homosexuals. ${ }^{54}$ Over the next decades, more states adopted similar tactics, and by 1954, California created the Department of Alcohol Beverage Control to revoke alcohol licenses and shut down establishments that let "sexual perverts" gather. ${ }^{55}$

Lewdness and destitution among Americans were partial symptoms of the Great Depression. Men were increasingly laid-off from work and struggled to find jobs, to the point that psychologists and social workers compared the effect of losing control over income to shellshock during World War I. ${ }^{56}$ Regardless of the number of cases, transient men and women were known for using sexual favors in exchange for money and food. Some fictional accounts of depression-era vagrancy depicted both gay and straight men

\footnotetext{
52 Bronski, 119.

${ }^{53}$ Chauncey, 337.

${ }^{54}$ Chauncey, 337.

${ }^{55}$ Lillian Faderman, The Gay Revolution: The story of the struggle, (New York, NY: Simon and Schuster Paperbacks, 2015), 7.

${ }^{56}$ Canaday, 95.
} 
alike performing sex work and favors for men in the absence of any other income. ${ }^{57}$ With the Depression also came a trend of family fracturing as men left their marriages and children in large numbers. ${ }^{58}$ By 1937, polls showed that at least one third of Americans favored federal subsidies to encourage and maintain the marriages of younger American men and women. ${ }^{59}$ New Deal programs like the Civilian Conservation Corps were created by the federal government to prevent unemployed men from becoming transients. ${ }^{60}$ At one such New Deal camp, there were explicit rules that prohibited the men there from being naked more than necessary or forbade men from "lounging" on the beds of other men. ${ }^{61}$ Similar rules appeared in the military because officers observed that soldiers intentionally, and unintentionally, would be in sexual contact with other men when in such close quarters At the same time, other officers and officials were concerned that homosexual men, when sharing a bed, would inevitably have sex while heterosexual men were in danger of being victimized if he shared a bed with a gay man. ${ }^{62}$ The existence of gay men and women were rarely seen beyond sex by police and, because of the seriousness with which law enforcement pursued gay men, little headway for acceptance or decriminalization was possible for the disconnected gay communities against these overarching legal structures.

${ }^{57}$ Canaday, 100.

${ }^{58}$ Before Stonewall, 15:45.

${ }^{59}$ May, 42.

${ }^{60}$ Canaday, 92.

${ }^{61}$ Canaday, 111.

${ }^{62}$ Bérubé, 39 and 220. 


\section{The Campaign for Human Rights}

Henry Gerber described himself in 1925 as stubborn, writing "whenever I

conceive of an idea, I drop everything else and work on it to its conclusion." ${ }^{63}$ Many decades later, in 1962, he wrote a piece for $O N E$ that described his experience as a gay man in the 1920s, and his experience cemented his place in the history of gay rights. While a federal employee of the post office, he sought help from friends and his boss in making a minority rights organization, all of whom told him it was ill-advised. ${ }^{64}$ To found the organization, Gerber, six of his friends, and a lawyer applied to the state of Illinois in 1925 and, most likely due to the ambiguous title of the society, the application was accepted. ${ }^{65}$ Gerber copied the name of a German homophile organization for his own in Illinois, calling it "The Society for Human Rights." The goals of the society were to "reach as large a number as possible," to engage in lectures that emphasized keeping homosexual acts to private spheres, to publish a magazine called Friendship and Freedom to "keep the homophile world in touch with the progress of our efforts," and to "win the confidence and assistance of legal authorities and legislators." were ideals, whereas the reality was such that, before being disbanded, the Society published just two issues of Friendship and Freedom mostly financed and authored by Gerber, who was the Society's secretary. So few of these publications were printed that no copies seemed to exist by the 1970 s. ${ }^{67}$

\footnotetext{
${ }^{63}$ Henry Gerber, Draft of "Society for Human Rights" [ca. 1962], Box 1, Folder 2, Henry Gerber Collection.

${ }^{64}$ Gerber, Draft of "Society for Human Rights," Henry Gerber Collection.

${ }^{65}$ Gerber, "The Society for Human Rights," 6-7.

${ }^{66}$ Gerber, "The Society for Human Rights," 6.

${ }^{67}$ Gilgamesh et al.
} 
Gerber mentioned just three other members by name. The Society's leadership did not expand beyond a few members, which included Gerber, John, who was an African American street-preacher and elected president of the Society, and Al, who was the Society's vice president. There were few other members and one, named Ralph, was only described as working with a railroad company but did not actively engage in the Society for fear of losing his job. ${ }^{68}$ Gerber often lamented in numerous sources that "homosexuals don't organize. ${ }^{\prime 69}$ Namely, apathy and fear were why Gerber believed few wanted to join, or be associated with, his organization and efforts. Gerber's experience of the gay community in 1925 was such that he described them as "ignorant in sex matters by reason of the public suppression of the subject," others were "too depraved" to be a part of a public movement for respect, and some told Gerber that gay relationships only appealed to them as the act was forbidden. ${ }^{70}$ The greater and more significant issue facing gay men in the 1920s, however, was the law.

Beyond the gay community, Gerber's society required the support of outside influencers such as legislators and medical professionals, but none proved willing. Gerber was aware that doctors or psychiatrists would be more concerned with their livelihood and reputation and, "would most likely refuse to be mixed up with unknown 'perverts'." ${ }^{\prime 1}$ Sodomy was its own crime while other homosexual activity was defined as disorderly conduct. Sodomy carried a one to ten year prison sentence in Illinois while other states had different punishments, such as Georgia, where sodomy carried a life

\footnotetext{
${ }^{68}$ Gerber, "The Society for Human Rights," 8.

${ }^{69}$ Gilgamesh et al. Gerber, "The Society for Human Rights," 7.

${ }^{70}$ It is worth noting that these sentiments echoed the lack of education and awareness many had in respect to sexuality, reflected popular fears of unchecked perversion, and underscored the popularity of subversive and illegal activity in the height of the Prohibition era.

${ }^{71}$ Gerber, Draft of "The Society for Human Rights," Henry Gerber Collection.
} 
sentence. ${ }^{72}$ Sodomy was legally the same charge as the sexual assault of a child and, according to Gerber, was applied the same way in cases of both forced and consensual homosexual sodomy, heterosexual sodomy, and bestiality as they were all considered a similar "crime against nature."73 Therefore, the popular concern among men of the gay community over legal consequences turned out to be warranted.

In the interwar period, the time between world wars, nonviolent sodomy in the Army carried a five year prison sentence of hard labor while the Navy had a ten to twelve year punishment. In addition to jail time, a soldier convicted of sodomy was likely to lose all pay and receive a dishonorable discharge. ${ }^{74}$ Within military prisons, like Portsmouth Naval Prison, wardens separated gay prisoners from the rest of the prison population, while some like Fort Leavenworth made inmates convicted of sodomy wear the letter ' $D$ ' on uniforms to denote them as 'Degenerate.' ${ }^{75}$ Anti-gay legislation in this time was widespread beyond the cities, especially in the military. However, historian Margot Canaday found that court-martials for sexual activity between men, before World War II, were rarely for consensual acts between men, but instead punished soldiers that were either violent, or garnered too much public attention. When Congress proposed legislation in both the 1920s and 1930s that would target gay servicemen for any homosexual activity with a threat of military discharge, the military continued to rely on common anti-sodomy laws. ${ }^{76}$ Such laws which specifically targeted the physical act of sodomy were difficult to prove, so much so that local police forces preferred to charge

\footnotetext{
72 Gerber, "The Society for Human Rights," 8.

73 Gerber, "The Society for Human Rights," 7.

${ }^{74}$ Bérubé, 129.

75 Bérubé, 130. According to Bérubé, during the 1930s, $40 \%$ of all new prisoners at Portsmouth were convicted of either sodomy or other sexual crimes that were not the rape of women.

${ }^{76}$ Canaday, 58.
} 
gay men for indecency. In this way, the armed forces mirrored the civilian legal system, except the military did not as yet carry misdemeanor designation for homosexuality. In part, the military appeared more concerned with public scrutiny and its image as unit commanders frequently blamed civilian immorality for homosexual activity and other forms of perversion. ${ }^{77}$

The fate of the Society for Human Rights was emblematic of the uphill battle all early homophile or gay rights groups faced in the United States. Unbeknownst to Gerber and John, even though they held regular meeting for the Society at Al's home, Al was bisexual and married. One day, Al's wife called a social worker and the police to report the homosexual nature of the Society. ${ }^{78}$ Gerber recalled that a detective and local reporter arrived at his apartment in the early morning, entered without explanation, were confused that he was alone, and then arrested him. The detective seized his typewriter, his notary diploma, personal diaries, and all materials relating to the Society before Gerber himself was taken to the police station and imprisoned, all without a warrant. John, Al, and a man with whom Al had been with the night before were all arrested as well. By morning, a local paper had published an article, as Gerber recalled, "Strange Sex Cult Exposed," that accused the men by name and described the society as one that "urged men to leave their wives and children." ${ }^{79}$ In 2012, the author St. Sukie de la Croix appears to be the first to find an inconsistency in Gerber's account that was never corrected, namely that the article was actually in the July 13, 1925 edition of the Chicago American, under the

\footnotetext{
${ }^{77}$ Canaday, 72.

${ }^{78}$ Gerber, "The Society for Human Rights," 8.

${ }^{79}$ Gerber, "The Society for Human Rights," 8.
} 
headline "Girl Reveals Strange Cult Run by Dad." ${ }^{" 00}$ Gerber was named in the paper as the publisher of the "cult magazine," with his full name, occupation, and address listed. ${ }^{81}$ Consistent with the prevailing homophobic attitudes of the time, a postal inspector at the subsequent trial argued that the group deserved severe punishment, "for infecting God's own country." 82

At sentencing, the evidence presented to a judge, to incriminate Gerber, was some makeup to prove of his effeminacy as a gay man, that Gerber insisted even forty years later was not his, along with an excerpt from his diary which stated "I love Karl." Gerber explained that by this point, because he and the other defendants were gay, every juror in the courtroom was immediately biased against them. ${ }^{83}$ After the last of three trials was concluded, Gerber recalled a detective remarking "what was the idea of the Society for Human Rights anyway? Was it to give you birds the legal right to rape every boy on the street?" ${ }^{\prime 4}$ At the first court appearance, the group was only charged with the crime of sending obscene materials through the mail, though Friendship and Freedom contained no such material. But by the third court appearance for Gerber and other members of the Society, a new judge threw out the case and described the initial arrest of the group as outrageous because it was done without a warrant. While the case was thrown out, $\mathrm{Al}$ had been charged for a separate crime of disorderly conduct and paid a fine. ${ }^{85}$ Because the

\footnotetext{
${ }^{80}$ St. Sukie de la Croix, Chicago Whispers: a history of LGBT Chicago before Stonewall, (Madison, WI: University of Wisconsin Press, 2012) 82. Most likely the 40 year gap between Gerber's experience with the police and his recording of events for ONE, there were mistakes in recollection that are frequently in the cited history. De la Croix did note some other inconsistencies with Gerber's timeline, but for the most part the overall story still remained the same

${ }^{81}$ De la Croix, 83.

${ }^{82}$ De la Croix, 83.

${ }^{83}$ Gerber, "The Society for Human Rights," 9.

${ }^{84}$ Gerber, "The Society for Human Rights," 10.

${ }^{85}$ Gerber, "The Society for Human Rights," 10.
} 
popular image of homosexuality was sexual in nature, police had expected to find him and other gay men in the progress of committing sodomy, believing that an organization of gay men could serve no other purpose than a sexual one. They did not gather any proof of a crime before arrest.

Gerber was initially released from prison on bail and tried to return to the post office, but found that he had been suspended, pending investigation. Even though his property, which included his personal diaries, were all returned by the police department, many of his possessions were retaken and kept by the postal inspectors. A few weeks later, Gerber was officially no longer a postal worker and received a letter that described him as having committed, "conduct unbecoming of a postal worker." ${ }^{\text {" Un }}$ Unemployed, without a hearing to argue his case for employment, Gerber went on to call that moment of formal dismissal "the end of the Society for Human Rights." ${ }^{17}$ Despite great aspirations, Gerber's society had failed, and despite its place as the first such organization in the United States, illustrated the commonplace experience of gay men and women before World War II.

Writing in 1962, Gerber had viewed his early attempt at a gay rights organization as akin to Abraham Lincoln, that if he could have succeeded, he would have been known in history as delivering the downtrodden gay man to a more free future, though conceding that he himself would have benefited, too. The Society did send small, early ripples into the American gay community though. Harry Hay recalled that one of the first gay men he met as a young man while cruising Pershing Square was an older man named Champ Simmons. Hay would tell others that this man brought him 'out' and introduced him to

${ }^{86}$ Gerber, "The Society for Human Rights," 10.

${ }^{87}$ Gerber, "The Society for Human Rights," 10. 
the gay culture. Simmons had not been a member of Gerber's Society for Human Rights, but had encountered it and its members and described the failed organization to Hay. This encounter remained in Hay's memory long into the 1970s, when he told early gay historians about the encounter. ${ }^{88}$ In reality, Gerber was not the 'Abraham Lincoln' for gay rights because, in his words, he was "up against a solid wall of ignorance, hypocrisy, meanness and corruption" and, "The wall had won."

Except for existing, however, the Society for Human Rights accomplished very little. As a direct result of founding that organization, Gerber went to jail, was publically shamed in the news, lost his livelihood, and had to leave Chicago to find work. Eventually, he moved to New York and applied to work in the same office as a friend he had worked with in the Army. In New York, his friend recommended him to the officers in charge of an Army printing office and he accepted the invitation. ${ }^{90}$ A 1978 history seminar hosted by $O N E$ described Gerber's initial conversation with the commander at that office. In that conversation, the commander acknowledged that even though Gerber lost a federal job for being gay, "the Army doesn't really care about that sort of thing as long as you don't get too public about it." ${ }^{\prime 91}$ Afterwards, the commanding officer invited Gerber to reenlist in the Army.

\section{Gay Men and the American Military}

The concern over the public's perception of the military was common. For instance, in one army-published newspaper in 1919, the same paper Gerber himself had

\footnotetext{
${ }^{88}$ James T. Sears, Behind the Mask of the Mattachine: The Hal Call Chronicles and the Early Movement for Homosexual Emancipation, (New York, NY: Routledge, 2011), 115. Gilgamesh et al.

${ }^{89}$ Gerber, "The Society for Human Rights," 6 and 10.

${ }^{90}$ Gerber, Draft of "The Society for Human Rights," Henry Gerber Collection.

${ }^{91}$ Gilgamesh et al.
} 
worked for, a soldier stationed with the American occupation force in Germany complained about another soldier. The soldier in question was said to be wearing rouge, or other makeup, and a hair curler in public. Such actions resulted in the local populace making "several remarks about him and in the end it reflected upon the soldiers of the army." 92 Effeminate and gay soldiers being seen by the public was apparently detrimental to the image of the United States military and thus they were punished by their chains of command. Public discourse of the time unsurprisingly tended to lambast the government for possibly allowing 'normal' soldiers to serve alongside gay soldiers as it would compromise military unity and the morals of personnel, and ultimately threaten the reputation of American power around the world. ${ }^{93}$ Conversely, government officials tended to blame civilians for homosexuality within the military ranks, depicting perversion as an outside social influence that infected the armed forces. One such case occurred when rumors spread that gay men were being released from prison by reform advocates and sent into the Navy. This rumor spurred a naval captain to complain to the War Department that if gay men were allowed to return to service, after being convicted for "indecent and unnatural practices," it would "result in the contamination and demoralization" of the purely "honorable and decent men of the naval service."

This prejudice against homosexuality in the military caused a need for secrecy, even among male victims of sexual assault. For military judges, the fact that a man was gay, or had previously performed gay activities, was deemed a substitute for consent to

\footnotetext{
${ }^{92}$ De la Croix, 74.

${ }^{93}$ Aaron Belkin, Bring Me Men: military masculinity and the benign façade of American empire 1898-2001 (New York, NY: Columbia University Press, 2012), 64.

${ }^{94}$ Canaday, 75-76.
} 
be assaulted by other men..$^{95}$ The combination of strict anti-sodomy laws, combined with the perception of homosexuality as infectious and a violation of military masculinity, resulted in an environment where both consensual and non-consensual interactions between men had to be kept secret from commanders for fear of court-martial punishment. Even though the American armed forces before the outbreak of World War II did not condone homosexuality, the depiction of the ease with which Gerber was able to reenter the Army and eventually retire, despite his legal history, relied upon the secrecy of his sexuality rather than the non-existence of it. After his reenlistment Gerber was involved in efforts to connect the gay community, despite the failure of the Society for Human Rights, through the development of a pen pal club while stationed as an army volunteer at Governors Island in New York. ${ }^{96}$

${ }^{95}$ Canaday, 83.

${ }^{96}$ Gilgamesh et al. 


\section{Chapter 2: Going to War}

By 1936, whatever openness or acceptance for homosexuality there had once been in Germany was no longer. Bertram Schaffner, born in 1912 in Erie, Pennsylvania, traveled to Germany with his German mother in the mid-1930s to attempt to get Jewish relatives out of the country. Schaffner was gay and he recalled going for a walk one night in Berlin and being told by another man, whom he was trying to meet and have sex, "It's extremely dangerous for us to be seen talking. Because everybody is watched, [and] everybody is subject to immediate arrest... if you had stopped to talk to each other because a sexual reason... please [let's] separate now." ${ }^{\prime 97}$ They went their separate ways and Schaffner became more careful in public. Upon returning to the United States, he would later enlist in the Army and serve throughout World War II as a doctor, achieving the rank of Major and secretly helping gay soldiers to avoid public humiliation.

World War II was a turning point in the twentieth century, expanding the global reach of American military power and vastly impacting American society. With conflicts across continents far from the United States, the nation prepared for a war which inadvertently changed the landscape of the gay community. At the start of World War II, the United States armed forces lacked the manpower needed to fight such a wide-ranging conflict. The National Guard was 6000 men short of its 1939 goal of 251,000 and even worse off was the Navy aviation corps which had 2602 men for its 16,000 open positions. Barely more than 800,000 Americans were in service across all branches of the military, over 200,000 short of government peacetime goals. ${ }^{98}$ American forces, across the board,

\footnotetext{
${ }^{97}$ Bertram Schaffner: Interview 41773. Visual History Archive, USC Shoah Foundation, 1998: Segment 72. ${ }^{98}$ Christina S. Jarvis, The Male Body at War (DeKalb, IL: Northern Illinois University Press, 2004), 11. Taylor, 8 .
} 
did not reach their enlistment goals. During the late 1930s, privates in the military were paid half the rate of the Civilian Conservation Corps, and at the same time some judges recommended military service as a potential punishment in some courtrooms, making military service unpopular. Before the United States' entrance into the war, every branch of the United States armed forces were lacking in manpower. ${ }^{99}$ As world superpowers waged war in Africa, Asia, and Europe, the United States made the difficult transition to a war-ready nation. The military's mass movement of people and resources brought a diverse sampling of all local cultures under a single, unified power structure that promoted ideals of citizenship and provided opportunities for men to define themselves as Americans. ${ }^{100}$

\section{The Draft Asks All}

In June of 1940, bills were introduced in Congress by both parties to begin a peacetime draft in preparation of a coming war. Even though war waged across the seas, many Americans did not believe there was impending danger, and thus many government representatives, believed conscription was only a last resort to national defense. But by September 1940, President Roosevelt signed into law the first ever American peacetime

draft. The creation of the Selective Service required medical examinations of all men who were supposed to serve in the military to determine if they were healthy enough to be soldiers. Definitions of health in the 1940s were not limited to outward appearance and included other factors like organ health, aided by new developments in x-ray technology,

\footnotetext{
${ }^{99}$ Bérubé, 1.

${ }^{100}$ Taylor, 3.
} 
and mental health, spurred by the growing psychiatric profession. ${ }^{101}$ Thus, to be considered a healthy soldier, potential recruits had to endure not only physical fitness examinations but mental health and personality ones as well. Navy advertisements that read "Healthy Bodies - Active Minds" underscored the non-physical components of military selection and training. The Committee on Physical Fitness expressly sought to create men who "reject soft living and take pride in physical vigor," and that mentally developed a "will to win."102

Schaffner, now back in the United States, was drafted in October of 1940 and entered active service by April 1941. Despite being a part of a Quaker community, he did not seek to be a conscientious objector status because of the harm he had witnessed Nazi Germany inflicting upon its own Jewish citizens. ${ }^{103}$ His first assignment was Governors Island in New York, where he was an examiner for draftee screening. He described the purpose of his job as a psychiatric evaluator to decide who was fit for service and who would break down in combat. Specifically, he recalled, he was "not to accept any gay people into the Army." 104 This directive was in contrast to the recruitment practices of allied countries in 1941 and 1942, like Canada, that did not outright ban gay recruits as some medical examiners were not even aware homosexuals should be barred from service. ${ }^{105}$ Regardless of that difference, the primary goal of recruit and draftee medical examination was to determine who was healthy enough for war.

\footnotetext{
${ }^{101}$ Jarvis, 63. Taylor, 9. The new draft called for: "Every male citizen of the United States and every other male person residing within the United States, who is between the ages of 18 and 45 at the time vested for his registration, shall be liable for training and service in the land or naval forces of the United States."

102 Jarvis, 65 and 67.

${ }^{103}$ Schaffner, Segment 92.

${ }^{104}$ Schaffner, Segment 86-87.

${ }^{105}$ Paul Jackson, One of the Boys: Homosexuality in the Military during World War II (Montreal, Quebec and Kingston, Ontario: McGill-Queen's University Press, 2010), 36. Canadian policies more closely resembled Great Britain than it did the United States. Like Bérubé, Jackson examined many aspects of
} 
Psychiatric professionals in the United States believed that the addition of their research into mental health screening could help determine if any man was unchangeably 'soft,' such that they would not become a "psychiatric casualty," or someone who might suffer an emotional breakdown. In this way, doctors hoped to avoid the far too common cases of "shell shock" seen in World War I, thereby burdening military combat units, the armed forces, and the country. ${ }^{106}$ Physical, mental, and moral health was categorized and classified during the selection process, leading to terms like I-A (1A), I-B (1B), or IV-F (4F). ${ }^{107}$ 4F men were considered unacceptable for military service and disqualified a number of conditions including physical disabilities, "moral defects" such as homosexuality, or "personality defects" like nervousness that could lead to breakdowns in combat. ${ }^{108}$ Of the first one million men examined by the selective service, more than forty percent were designated 4F, and by the December 1941 attack on Pearl Harbor, 1.1 million men were deemed unfit for military service. Government authorities directly linked draft rejection numbers with national health as a whole, such that President Roosevelt described how "he was worried about the health of the people of the United States." 109 Thus, military-based health examinations, and the factors which those exams recorded, became the litmus test for the overall health of the United States. These

homosexuality in World War II from recruitment to discharge, from psychiatry to combat, but in a Canadian context.

${ }^{106}$ Bérubé, 16. Jackson, 36, 123. Canadian medical examiners appeared to accept more recruits based on their physical health and used a recruit's reaction to boot camp as a litmus for their mental fortitude in the field, whereas the United States attempted to determine mental and psychiatric fortitude at recruitment. Gay servicemen were only referred to Canadian psychiatric professionals if they were causing trouble within a unit.

${ }^{107}$ Jarvis, 59. These classification were quantifiable, to the point that the average dimensions of a $1 \mathrm{~A}$ man were exact figures like 68.1 inches tall, 152 pounds in weight, and a chest size of 34 inches; they were also free of disease or, later in the war, were receiving treatment for certain venereal diseases.

108 Jarvis, 59.

${ }^{109}$ Jarvis, 61. 
numbers invoked images of a physically deteriorating American populace left by the Great Depression, rather than the image of strength that military training would hopefully provide.

American Medical Corps officers in 1942 described homosexuality as "a definite mental abnormality" and as an incurable form of "sexual psychopathy."110 The classification of gay men as schizoid and paranoid personalities followed the belief that gay men could behave normally in a civilian space, but that they were ultimately too introverted and nervous to be of use in the military and might, in fact, be victimized by other men. Conversely, the claim that gay men were psychopaths, as Alan Bérubé explained, was because they were "irresponsible troublemakers who were unable to control their desires or learn from their mistakes and thus threatened other men."111 Popular media and military policies reinforced the stereotypes of gay men as threatening the military or as liabilities to their units, and struck a division between homosexuality and military service. ${ }^{112}$ Although published after World War II, the 1951 book From Here to Eternity, by James Jones, received fame for its realistic (though fictional) portrayal of soldiers' life before and after the attack on Pearl Harbor in 1941 and was later adapted into a Oscar-winning movie with the same title. ${ }^{113}$ In one chapter, the main character and other soldiers are detained by military police as a part of an investigation into homosexual activity in Waikiki. Throughout the chapter, soldiers talk about the existence of queer-chasing soldiers and are told by FBI investigators, civilian

\footnotetext{
110 Jarvis, 74.

111 Bérubé, 15.

112 Jarvis, 73.

${ }^{113}$ Furthermore, From Here to Eternity was considered a significant American novel evidenced by its National Book Award in 1952, the year immediately after its publication.
} 
police, and MPs to identify anyone talking to men who were possibly gay at a local bar.

The characters do not identify a fellow soldier. The investigating lieutenant then explains to one of them, "You don't have to lie to me... We're not trying to put the finger on any of you men. We're trying to protect you from these people." ${ }^{114}$ Here, gay people were not considered real men and, perhaps paradoxically, they were dangers from whom police and the FBI needed to protect soldiers. This fictional portrayal was a familiar scenario that many gay servicemen feared. Before World War II ended, soldiers like a sailor named Charles "Chuck" Schoen saw how San Francisco and its gay community boomed with the war effort. However, he still had to judge the risk of any encounter with another man, worried that "this is the guy to go with-he isn't one that will turn me in."115 The official narrative that gay men threatened those serving in the armed forces expanded with the draft when gay men were labeled as $4 \mathrm{~F}$. In this way, the gay draftee was not only unfit to serve in the armed forces, but should such a man be allowed into service, he would be a threat to other men, and furthermore he constituted "a demoralizing element in any organization." ${ }^{116}$ Not only would he then be of no use to the military, he was a detriment to any workplace in American society.

\section{Opportunities for Equal Rights as Soldiers}

The need to mobilize a nation into war required a great number of both soldiers and civilians to be moved into service and production. More than twenty million women moved beyond the confines of families and homes during World War II, gaining

\footnotetext{
${ }^{114}$ James Jones, From Here to Eternity (New York, NY: Charles Scribner's Sons, 1951), 421.

${ }^{115}$ Charles S. "Chuck” Schoen, in My Country My Right to Serve, 43.

116 Jarvis, 74.
} 
increased autonomy and economic mobility that was not available before the war. ${ }^{117}$ This shift led to women gaining access to previously limited professions such as war industry and the armed forces. Less than a year after the proposal of the draft, the Women's Army Auxiliary Corps (WAAC) was proposed in a bill by Congresswoman Edith Nourse Rogers (R-MA) in May 1941; later its name changed to the Women's Army Corps (WAC). President Woodrow Wilson once told his staff, before World War I, that "women's place was in the home, and the type of woman who took an active part in the suffrage agitation was totally abhorrent."118 Because there had been no official women's army unit, in World War I, women who participated in previous wars were classified as civilians, and despite becoming ill or injured in the fulfillment of their wartime duties, they did not have a right to similar compensation as men. ${ }^{119}$ Twenty-five thousand women served in a variety of capacities in Europe during World War I, including work on the frontlines. Of them, 350 died in combat. ${ }^{120}$ But the sacrifice and service given women in the Great War could not be ignored, and by 1917 President Wilson told the Senate that "we have made partners of the women in this war; shall we admit them only to a partnership of suffering and sacrifice and toil and not to a partnership of privilege and right?" 121 Making women into soldiers officially protected them from discrimination and sexual exploitation, but had to be balanced as a publicly acceptable and feminine image. $^{122}$

\footnotetext{
${ }^{117}$ M. Michaela Hamph, Release a Man for Combat: The Women's Army Corps During World War II (Cologne, Germany: Böhlau Verlag, 2010), 237.

118 Robert P. Saldin, "Strange Bedfellows: War and Minority Rights," World Affairs 173:6 (2011), 58.

${ }^{119}$ Meyer, 11.

${ }^{120}$ Saldin, 58.

${ }^{121}$ Saldin, 59.

${ }^{122}$ M. Michaela Hamph, “'Dykes' or 'Whores': Sexuality and the Women's Army Corps in the United States during World War II,’ Women's Studies International Forum 27 (2004): 16.
} 
Historically, military service combined ideals of citizenship, national sovereignty, and manhood, creating a warrior status predicated on the protection of women and children. ${ }^{123}$ One notable argument against the creation of the WAAC was by Congressman Andrew Somers (D-NY) on March 17, 1942, who said in Congress, "A women's Army to defend the United States of America! Think of the humiliation. What has become of the manhood of America, that we have to call our women to do what has ever been the duty of man?"124 Somer's arguments, like President Wilson's before him, were similar to those against suffrage rights for women early in the twenty-first century, hinging on the belief that women did not equally participate in citizenship because they could not serve and sacrifice their lives for the country. ${ }^{125}$ M. Michaela Hamph argued that "the construction of a hegemonic military masculinity is centered on combat... and has depended on the exclusion of the 'other', the 'overt homosexual', the 'feminine', and 'ethnic other'."126 Because women were not men, many Americans believed that women simply had no place near wars, and for women to be involved in warfare implied that American men had failed to be protectors and adequate warriors.

Mainstream media also claimed that military training for women would challenge the physical dominance of men by masculinizing women. At the same time, the media zeroed in on birth control information provided to WACs as supposed proof of promiscuity and some accused the Women's Army Corps of prostitution towards servicemen. ${ }^{127}$ In the same vein, Lisa Meyer argues that, historically, the image of the

\footnotetext{
${ }^{123}$ Hamph, 14.

${ }^{124}$ Meyer, 13.

${ }^{125}$ Saldin, 58.

${ }^{126}$ Hamph, 14.

${ }^{127}$ Hamph, 16.
} 
'mannish woman' was often a representation of lesbianism before World War II, but during the war, because military service was a masculine profession, a mannish woman was instead an image that represented public fears over women outside of their traditional spheres and participating in military service. People worried that women would be encouraged or forced by the government to present in a masculine fashion and assume a masculine identity. ${ }^{128}$ For the duration of their service, many WACs were forbidden from wearing dress slacks that had been issued with their uniform. Some, like Lilian Barbera, a WAC from Boston, were annoyed that they could not wear pants and did so anyway when away from their commanding officer (CO) and on leave. While Barbera's $\mathrm{CO}$ saw her group of servicewomen wearing their slacks, and disciplined them with leave restrictions and extra work, such individual actions pushed against the norms of military service represented greater shifts beyond traditional American culture during war. ${ }^{129}$

The traditional definition of military service as a masculine realm reinforced the idea that the entrance of women into military service, like that of gay men, was destructive to military culture. ${ }^{130}$ The warrior ideal, culturally, was a man who could separate and destroy any relationship to non-masculine aspects of themselves such as emotion and weakness, and who could fully commit to one side of a binary that was either soldier or civilian, either masculine or feminine. ${ }^{131}$ When Esther Herbert, a lesbian WAC, was transferred across the country, she described in letters to her partner Marvyl Doyle, whom she had met in the Army, that she was treated differently from other women. "Of course I am the only service gal on the train and everyone practically stares

\footnotetext{
${ }^{128}$ Meyer, 6.

${ }^{129}$ Lillian Barbera, And So I Joined the Army (Barbera Family Publishing, 1997), 59.

${ }^{130}$ Meyer, 4.

${ }^{131}$ Belkin, 5.
} 
the clothes off of me" Herbert described, "Every time I go to the ladies lounge... people talk [and also] stare at me as though I were nuts." 132 Another woman, Johnnie Phelps recalled that, like male recruits, she and other women went through basic training and although some women were not able to complete training. She described that "the guys who trained us did not allow for the fact that we were women at all. We trained exactly like any other military unit."133

Participation in the wartime military was opening new opportunities for equal rights, but this push also came with restrictions and limitations that continued to reflect the values and power structures of the United States. Organizations that supported women's rights were split in regards to the importance of military service. But while African American and socialist women's organizations saw the opening of military service as a way to advance opportunities for equality and civil rights beyond the war, primarily white women's organizations focused on military service as “a temporary sacrifice" until the war's end. ${ }^{134}$ When on leave in Europe, Lillian Barberarecalled that servicemen enjoyed accompanying her and other female soldiers throughout liberated European cities, but recalled that the same men did not like that women were soldiers. "These boys treated us like they would their own sisters at home... Here were Americans who, although they did not approve of American girls in the Army, realized that we, too, were away from home, were lonely." ${ }^{135}$ Even when designated as an official branch of the Army, the same for women's corps in other branches of the military, servicewomen

\footnotetext{
132 Esther Herbert to Marvyl Doyle, 22 February 1944, Box 1 Folder 3, Herbert and Doyle Collection.

133 Johnnie Phelps, in My Country My Right to Serve, 38.

134 Hamph, 16.

135 Barbera, Lillian, 41.
} 
were still described in public and government discourses as supplemental to the regular Army forces and only noncombatant in nature. ${ }^{136}$

These examples from the Women's Army Corps suggest that World War II policymaking was a contentious arena for assigning (and limiting) the rights of many citizens through their service. The elite status of military officers remained reserved for straight, white men, especially in combat positions, which often excluded African Americans and women from equal status in military participation. ${ }^{137}$ Moreover, the armed forces were racially segregated and War Department policy refused to integrate because "to make changes would produce situations destructive to morale and detrimental to the preparation for national defense." ${ }^{138}$ Early in World War II, combat participation and commander ranks were privileges reserved for white troops. Black troops were often relegated to the rear lines. More than one million African American soldiers served in the war, and units were racially segregated throughout the war, but increasing casualties and manpower shortages put pressure on the military to finally place black units in combat roles. ${ }^{139}$ The Soldier Voting Act of 1942 fundamentally confirmed the connection of military service and civil participation by ensuring the right of soldiers to vote in elections back home with absentee ballots. This law also eliminated poll taxes for soldiers serving abroad, typically used to prevent African Americans from voting in many states, making the bill the first expansion of African American voting rights since the Reconstruction era. ${ }^{140}$ This major change in voting rights, during a time of war,

\footnotetext{
${ }^{136}$ Meyer, 56.

${ }^{137}$ Hamph, 15.

138 Taylor, 17.

139 Saldin, 59.

140 Saldin, 60.
} 
underscores William Taylor's argument that military service provided not only new opportunities for many Americans, but promoted equality as citizens. ${ }^{141}$ This was not equally the case for all minority service members during World War II - gay men, women, and racial minorities.

Even as millions had to be drafted and mobilized in the wake of Pearl Harbor, the armed forces, in fact, only called for women to enlist six months after the United States declared war, firmly putting the military in competition with the wartime industry for women's labor. Military service was still not widely popular among women, but those in the service were convinced of their duty, as Herbert remarked in a letter: "It sort of makes me angry to meet my generation [and] realize what a bunch of flibbertigibbets they are. They gripe about the war but wouldn't think of doing anything about it. The army has not helped to make me closer to such women." ${ }^{142}$ But once enlisted, women were primarily placed in clerical and communication units, as it was believed that it would be inefficient to train women to perform jobs primarily assigned to men. ${ }^{143}$ Arguments in support of the official designation of a group of women as soldiers further included the argument that ideas of citizenship were directly linked to military service and that official recognition could secure veterans benefits, disability pensions, and privileges for women that were typically only reserved for male soldiers. ${ }^{144}$ By 1943, the then two-year-old auxiliary branch of the army was officially placed within the Army as the Women's Army Corps.

\footnotetext{
141 Taylor, 3.

142 Esther Herbert to Marvyl Doyle, 22 February 1944, Herbert and Doyle Collection.

${ }^{143}$ Meyer, 72.

${ }^{144}$ Meyer, 12.
} 


\section{The Gay American Soldier}

Beliefs underscoring why women should not partake in military service were the same arguments used to justify the exclusion of gay men from service. In the longer history of American masculinity, the supposed pacifying influence of women on men was often a subject of heated debate. Due to this stereotype, men who were too close to their mothers, wives, and simply women in general were frequently subjects of ridicule. In this way, men who did not conform to traditional understandings of gender and family were labeled as "sissies," "soft," and "womanlike," if not simply calling them women's names. ${ }^{145}$ In the late-nineteenth and early-twentieth centuries, common idioms routinely derided men by using women's names and declaring them not only woman-like, but the literal opposite of men. In 1916, for example, Theodore Roosevelt publicly called President Woodrow Wilson "Miss Nancy" for not declaring war. ${ }^{146}$ In World War II, this tradition continued as men who were designated $4 \mathrm{~F}$ were subjected to the same insults, reinforcing the stereotype that a feminine man was not a man at all.

The rationales behind the ban of gay men claimed they were a danger to other men, but even more, they were incapable of being effective soldiers. This belief corresponded directly to a broader history of American masculinity. Gay men were often discharged and disqualified from service based on stereotypes about their supposed femininity and how they failed to achieve proper manhood. Coupled with the perception of gay men and women as dangerous, and concern over the general role of men and women in wartime society, the idea that women could assume the jobs of men, and

\footnotetext{
145 Chauncey, 114-115.

${ }^{146}$ Anthony Rotundo, American Manhood: Transformations in Masculinity from the Revolution to the Modern Era. (New York, NY: BasicBooks, 2001), 272.
} 
therefore any masculine role, furthered public and governmental fears of lesbian relationships. ${ }^{147}$ Women, however, were typically those to whom gay men were compared. They therefore faced the additional burden of being in a field that privileged masculine attitudes and activity, but were subjected to public scrutiny for upsetting traditional gendered roles and military investigations into their sexuality unless they conformed to femininity in that male-dominated field.

There were legal issues as well because, before World War II, the act of sodomy, rather than homosexuality itself, was punishable by imprisonment within the military court system. The image of homosexuality that dominated public discourse at the first half of the twentieth century was that of the "fairy," an image of men who were overtly flamboyant and feminine. But, that version of public expression drew attention away from the more guarded and secretive gay lifestyle. During World War II, that distinction began to change. ${ }^{148}$ Meyer argues that the experience of gay men and women differed in significant ways. While regulations against men typically focused on sodomy and penalizing the act of sex between men, heterosexual sexual relationships were the encouraged norm for male troops. Conversely, servicewomen were regulated in respect to all sexual behavior. Furthermore, where the entrance of gay men into the armed forces was believed to infect the organization, and that sex between men weakened the individual or was a crime against nature, men were still able to fulfill a traditional gender role and differentiate themselves as 'proper' men. Meanwhile, the very entrance of women into the armed forces, much less lesbian women, challenged conception of the

\footnotetext{
${ }^{147}$ Meyer, 6.

${ }^{148}$ Chauncey, 103. Bérubé, 2.
} 
military as a masculine field and threatened the ideal of femininity as the inherent opposite of masculinity. ${ }^{149}$

The publicly effeminate lifestyle of some men in the gay community which was called the fairy lifestyle coupled with the illegal nature of gay relationships, was often the direct target of anti-gay public policy and harassment. At the same time, fairy culture fueled stereotypes that gay men were unmanly and the antithesis of American manhood. If gay men were dangerous to soldiers, then they were dangerous to the rest of the nation. The stereotypes about effeminate gay men, like female soldiers, would provoke social anxieties because these gay men were the physical embodiment of masculine failure. ${ }^{150}$ The fairy stereotype, though, was viewed by other gay men as a subset of homosexuality or queer identity, and the open nature of fairies garnered a reputation in major cities that spread across American culture. Among that subculture, wearing feminine clothing and makeup in public was a way to leave behind their previous, closeted, and expressionlimiting life. This style was a way to divorce themselves from traditional masculinity, to express previously suppressed feminine aspects of their personality, while some simply thought the fairy style would better attract other men. For many, the fairy lifestyle was a temporary phase, or a lifestyle they would have to again conceal, as they either discovered other ways to express their homosexuality or faced increasing limitations in professional choice and advancement. ${ }^{151}$

Yet not all gay men fit the "fairy" stereotype, forcing the War Department to create specific guidelines for the draft to disqualify more gay men. Before and after the

\footnotetext{
149 Meyer, 149.

${ }^{150}$ Chauncey, 115.

${ }^{151}$ Chauncey, 102.
} 
creation of the Selective Service, military branches gave directives to recruiters. Notably, they all addressed homosexuality in explicit terms. For the Selective Service, its first such guideline was in May 1941 and instructed induction stations to make homosexual tendencies another trait upon which to disqualify applicants. The Army's own circular at the same time labeled gay men as having a psychopathic personality disorder. The motivations behind these new regulations reflected the Navy's January 1941 directive to establish policies to get rid of and disqualify those who were mentally "unfit," or specifically people "whose sexual behavior is such that it would endanger or disturb the morale of the military unit." 152 While sodomy was not the worry of the WAC as it had been with the Army and Navy in years past, screening policy and programs within the branch were similarly "designed to discourage actions that might bring a negative publicity to the WAC." 153

Screening procedures to find lesbians were full of contradictions. In one sexual hygiene education course for officers, instructors taught that many homosexual women were the "very opposite in appearance of masculinity." However, lesbian women were described in the same guide as having "latent masculine characteristics," and that they "attempt to take on characteristics of the opposite sex"154 By 1942, with the United States officially at war, new War Department circulars defined a "normal" person as one who regarded sexuality with a "conventional attitude," juxtaposed by a homosexual or "pervert" who could be recognized by feminine appearance or by physical traits that fed

\footnotetext{
152 Bérubé, 12.

153 Meyer, 158.

154 Meyer, 159.
} 
homophobic stereotypes and were therefore "unsuitable for military service." ${ }^{\text {155 }}$ Draft board policies aimed to screen out venereal disease, perversion, and homosexuality were intended to further safeguard American health as a whole. ${ }^{156}$ Ironically, as men built up and trained their bodies through military training, the fear of gay men who willingly dressed in an effeminate manner, Chauncey argued, "seemed to ridicule and highlight the artificiality of the efforts of other men to masculinize theirs." ${ }^{, 157}$

\section{From Every Corner}

The government created explicit rules and regulations for the registering, examining, and drafting of potential soldiers, to sort through and disqualify many Americans. Although she met women whom she came to love, Johnnie Phelps explained that "I was an American first, a soldier second, a woman third, and whatever else came in a line fell in behind... In fact, I fought not to be a lesbian for many years after I knew I was one and knew it was 'wrong.' I wanted to be like everyone else." ${ }^{158}$ Social stigma, the fluid nature of sexual and gender identity, and the potentially harmful consequences of being identified as gay meant that the total number of gay soldiers can only be estimated. Alan Bérubé argued that between 600,000 and 1.6 million servicemen and women may have been gay during World War II by citing Dr. Alfred Kinsey’s 1948 survey and research. That study estimated that ten percent of white men between ages 16 and 55 identified as homosexual at some point in their life. Given the sixteen million

\footnotetext{
${ }^{155}$ Bérubé, 19. These stereotypes included physical traits like a wider anus, trimmed pubic hair, or a suppressed gag reflex.

156 Jarvis, 73.

${ }^{157}$ Chauncey, 115.

${ }^{158}$ Phelps, in My Country My Right to Serve, 39. Emphasis in original.
} 
Americans enlisted across all branches by the war's end, ten million of whom were drafted, ten percent would be a significant number. ${ }^{159}$

As servicemen were drafted from across the county, the same was true even for volunteer servicewomen, especially as Americans traveled to rapidly growing cities benefitting from war industries. ${ }^{160}$ Of the hundreds of thousands of women serving in the armed forces, they were from diverse regional, racial, and economic backgrounds but were overwhelmingly young and more than seventy percent were unmarried. ${ }^{161}$ Motivations and reasons for entering the military among gay recruits were as varied as the millions of other soldiers. For men, military service was a legal requirement (although a significant number were volunteers), but serving in uniform allowed young women, who were typically unable to escape familial and social pressures, to leave the family sphere and pursue opportunities beyond their home communities and economic constraints. ${ }^{162}$ At the same time, the United States required unprecedented numbers of soldiers, which Bérubé argued "denied the military the luxury of disqualifying large groups of Americans from the manpower pool." 163 This created a conflict within military ranks and caused gay recruits and soldiers to encounter expanding anti-gay military policies.

The week before his company was to deploy for the Pacific, James Lord was given permission to attend the Army Specialized Training Program (ASTP) because he

\footnotetext{
159 Bérubé, 289 .

160 James Lord, My Queer War (New York, NY: Farrar, Straus and Giroux, 2011), 17. In this memoir, Lord recalled that the opportunity to reach another part of the country was a major life event for many soldiers. He remembered another recruit saying "the folks back home'll never get over my getting a look at the Pacific Ocean.”

161 Meyer, 73.

162 Meyer, 75.

163 Bérubé, 2.
} 
had excelled in a special exam. He was transferred with other soldiers across the country in 1943 to Boston College, a Jesuit college, in Chestnut Hill, Massachusetts. ${ }^{164}$ The Army established the ASTP at Boston College during the war "in order to provide specialized training in foreign languages and engineering." 165 This program further highlighted the way that thousands of soldiers were transplanted across the country to new communities and opportunities as a part of the war effort. ${ }^{166}$ Thus, bases and major cities were where many gay men and women met people like themselves, some using the same slang and innuendo that had always been used by the gay community while others simply tried to find homosocial companionship and discovered more about themselves and others. ${ }^{167}$

Once in Boston, Lord encountered the local gay scene in a form he had never experienced. One night, a man offered to walk with him and soon asked him if he was gay. Lord had not known what the man meant, so the man then explained: "It's a password. We use it between ourselves so other people won't know we're talking about being queer." ${ }^{168}$ As a self-defense, relationships were rarely called gay or lesbian, in explicit terms. For the most part, the fear of being stigmatized or placed in legal jeopardy scared many gay soldiers into never directly talking about the subject of sexuality or romance. ${ }^{169}$

\footnotetext{
${ }^{164}$ Lord, 69 and 76.

${ }^{165}$ Boston College, "Jesuit History at BC," Office of the University Historian. (Accessed November 1, 2018)

${ }^{166}$ Ball State University, "The Army Specialized Training Program," Bracken Library Stoeckel Archives of Local History. (Accessed November 1, 2018.) Both Army and Navy students attended hundreds of schools for the ASTP between 1943 and 1944. Many of the ASTP applicants were expected to become officers, but by the end of the program in 1944 most were left as privates and deployed to combat areas to make use of their new skills.

${ }^{167}$ Bérubé, 100.

${ }^{168}$ Lord, 85.

${ }^{169}$ Bérubé, 105.
} 
Others also learned about themselves while in the military. When Rita Laporte joined the military in 1943, she had known she was different but thought she was unique in her feelings. When Laporte entered the WAC, she "learned then that I was not unique, but the inordinate fear of detection stayed with me." ${ }^{170}$ For Herbert, her sexuality appeared clear as she wrote her girlfriend Doyle, "The answer is yes this morning yes - I love you." She then looked at the men around her, considered the other soldiers on the train as she wrote her letter and thought, "[They are] seemingly okay... but I seem to be in love with Marvyl - the more I talk to them, the more I [am convinced]." ${ }^{\prime 171}$ At military bases, gay personnel were able to both learn about their own sexuality and pursue relationships in ways they never had the freedom to before.

Unlike on military bases, gay activity in cities fell under the jurisdiction of vice control policies and military police. Paul Hardman, a sailor, recalled that "San Francisco was notorious! I knew they had bars that were restricted because they were gay. In fact, that's how all the sailors and soldiers knew_it was like an advertisement." ${ }^{172}$ When Lord was first introduced to a crowded bar full of gay soldiers and civilians in Boston, he recalled one gay man, who identified himself as a $4 \mathrm{~F}$ as if to provide a disclaimer to his explanation, say, “Of course they [Military Police] know...That many gay servicemen you can't keep a secret. So what? Are they going to arrest a hundred, a hundred and fifty of Uncle Sam's soldiers and sailors every weekend?"173 MPs and queerbashers were still routine concerns for gay soldiers and, despite an emerging gay subculture in many cities, a constant fear of exposure forced many gay men and women to keep their romantic and

\footnotetext{
${ }^{170}$ Rita Laporte, "Living Propaganda,” The Ladder, June 1965, 21.

${ }^{171}$ Esther Herbert to Marvyl Doyle, 22 February 1944, Herbert and Doyle Collection.

172 Paul Hardman, in My Country My Right to Serve, 24.

173 Lord, 97.
} 
sexual interests to themselves. ${ }^{174}$ Even though the act of being gay was supposed to result in removal from service, Bérubé described how even men who acted 'queer' were typically accepted within their units and that "many outfits had at least one soldier who did his job especially well, was protected by a superior officer, and... won respect from the other men." ${ }^{\prime 175}$

Lord was only in the Army a few months when he told one of the men he reported to that he was queer. Even though this confession angered the other soldier, he was told “I don't want to hear about it. Just do your work, you hear me, and don't be late. Don't ever be late. ${ }^{1176}$ But Lord continued to worry that the other soldier would use knowledge of his sexuality as blackmail. As Meyer describes, in 1944 WAC officers had instructions on dealing with homosexual servicewomen that warned them to "expect some degree of homosexuality within their commands.” Romantic gestures and physicality between women were somewhat acceptable, but only when still adhering to societal social and racial norms. ${ }^{177}$ No longer confined to their hometowns, and now able to leave their bases, obtaining passes to go to cities that boomed from war industry became a major way for gay soldiers to explore their relationships with comrades and civilians, alike. ${ }^{178}$ Similar recreational interests became telltale signs of one's gay inclination, such as the reading of gay novels, women showing interest in sports and vehicles, or men embracing the arts with veiled references to gay life in musical performance. ${ }^{179}$ For Lord, the first time he told another soldier he was gay, he thought that his fellow soldier, named

\footnotetext{
${ }^{174}$ Bérubé, 99.

175 Bérubé, 184.

${ }^{176}$ Lord, 36.

${ }^{177}$ Meyer, 158 .

178 Bérubé, 98

179 Bérubé, 100-102
} 
Keith, might also be gay because of their mutual interest, but debated his decision. "Was everything to be entrusted to Beethoven and moonlight?"180 He confessed his affection to Keith, but Keith questioned if Lord was crazy or queer, then angrily told him 'Don't tell me. Don't even think about telling me... You're sick. Homo's are sick, perverts ought to see a doctor... Can't you control yourself?"181 Gay relationships, even if increasingly overlooked, were still met with open hostility or misunderstanding.

While stationed at Governors Island, Gerber published a newsletter for a penpal club called Contacts. Even though it was meant as a way for gay men to connect and communicate, Gerber insisted to others working on Contacts that the penpal club could not be only men and had to include women, in order to both bolster circulation to heterosexual men and to avoid the suspicion of authorities. But Gerber eventually stopped publishing once his army duties took up more of his time and the United States officially prepared for war. ${ }^{182}$ With that newsletter out of publication Manuel boyFrank, who later would become an officer of $O N E$, wrote to Contacts and Gerber to complain that, "We have got to get this thing [newsletter] going again. There is nothing in the country, there is no place in the country, where homosexuals can get together." 183

The centralized nature of basic training typically brought recruits from all regions and economic classes together for the first time, but the transient nature of military personnel and wartime requirements frequently broke up the barely-established gay social groups. "Honey - I'm going to miss you," wrote Herbert to Doyle and later lamenting in the same letter, "I love you and although I want you, want your arms around me - I'd

\footnotetext{
${ }^{180}$ Lord, 35.

181 Lord, 36.

182 Gilgamesh et al.

${ }^{183}$ Gilgamesh et al.
} 
settle for having you here to talk to - to be able to look at you." ${ }^{184}$ Herbert and Doyle wrote each other weekly, even after they broke up and began to date other people. Letters increasingly referenced wider groups of friends and fellow soldiers and mentioned who was dating, asking for relationship advice for themselves or other lesbians, who heard what rumors, or passing along messages from one WAC to another. To stay in touch with other transferred soldiers, gay soldiers like Woodie Wilson and his friends published a newsletter called the Myrtle Beach Bitch, which Bérubé described as "one of the first gay publications produced in the United States and possibly the earliest newsletter by and for gay servicemen." 185 The writing and publication of magazines and newsletters by soldier, for soldiers, was frequently used by many gay soldiers to connect with others. In 1944, however, Wilson and one of his friends were arrested by MPs and faced a court-martial for "misusing government property" by publishing their newsletter. ${ }^{186}$

\footnotetext{
${ }^{184}$ Esther Herbert to Marvyl Doyle, 22 February 1944, Herbert and Doyle Collection.

${ }^{185}$ Bérubé, 105.

${ }^{186}$ Bérubé, 144.
} 


\section{Chapter 3: Ending the Service of Gay Soldiers}

Alan Bérubé described a two-fold outcome of service for returning gay and lesbian veterans. In one aspect, many were able to serve their nation in its time of need and had come to the realization that they were not alone and had the opportunity to meet other gay soldiers from across the United States, thus beginning to create a national community and identity. For thousands of others, however, they were labeled as security threats, stripped of their benefits and rank, and assigned a stigma that would follow them into the civilian world. ${ }^{187}$

\section{The GI Bill}

After World War I, veterans were sometimes discharged with only sixty dollars as a reward for their service. It was not until the World War Readjustment Act of 1924 (also known as the Bonus Act) that the veterans of the Great War received bonus pay based on their time in service. ${ }^{188}$ But at the height of the Great Depression, the funds from the Bonus Act could not arrive soon enough. Thousands of veterans from across the country marched on Washington D.C. in 1932 along with their families, demanding immediate bonus pay for their Great War service that would not be doled out until 1945. Although a bill to provide those benefits sooner than 1945 failed in Congress, thousands of the protesting veterans did not leave the nation's capital and continued to live around the city in shantytowns before they were directly removed by the serving military; one General Douglass MacArthur, who would be famous in the future World War II and the Korean

\footnotetext{
187 Bérubé, 229.

${ }^{188}$ U.S. Department of Veterans Affairs, “About GI Bill: History and Timeline,” VA Education and Training. (Accessed January 20, 2019.)
} 
War, accompanied the troops to force these veterans out of the capital. ${ }^{189}$ The Veterans Administration (VA) describes this event as "one of the greatest periods of unrest our nation's capital had ever known."190

The Social Security Act of 1935 also attempted to further relieve the burden of the Depression as a groundbreaking welfare system. Its effects resonated across the United States by creating national benefits for the unemployed and the elderly. ${ }^{191}$ Early in World War II, social workers in cities central to wartime production noted that "the veteran of today remind[ed] them of the Depression migrant." 192 The government was concerned that, as the largest American war effort in history seemed closer and closer to ending, millions of veterans and their family may be left without medical care or finances, returning to civilian life. President Franklin D. Roosevelt explained in a June 1944 speech that, members of the armed forces who had "been compelled to make greater economic sacrifice and every other kind of sacrifice than the rest of us... are entitled to definite action to help take care of their special problems." ${ }^{193}$ The government's solution was the Servicemen's Readjustment Act, or GI Bill. Together, the GI Bill and Social Security would have resonating impacts on postwar American society. ${ }^{194}$

\footnotetext{
189 Paul Dickson and Thomas B. Allen. The Bonus Army: An American Epic (New York, NY: Walker \& Company, 2004), 81, 152.

${ }^{190}$ U.S. Department of Veterans Affairs, "About GI Bill: History and Timeline.”

${ }^{191}$ Canaday, 131. Canaday writes that despite numerous shortcomings, Social Security increasingly added benefits, like in 1939, by adding dependent and survivor benefits for wives of the men covered by social security. However it is notable that such benefits were only for men who were married and with families, thereby privileging government spending as for traditional families.

${ }^{192}$ Canaday, 137. Canaday described that, by the end of World War II, Social Security and the GI Bill were "the largest portion of welfare state expenditure at midcentury."

${ }^{193}$ Franklin Roosevelt, "Franklin Roosevelt's Statement on Signing the G.I. Bill. June 22, 1944." Franklin D. Roosevelt Presidential Library and Museum.

${ }^{194}$ Canaday, 139.
} 
The Servicemen Readjustment Act of 1944 was passed by Congress to provide its full benefits to soldiers that served for more than ninety days and that were discharged in any condition other than dishonorable. ${ }^{195}$ The 1944 GI Bill was debated between January and June of 1944 and finally signed into law by Roosevelt on June 22, 1944. It had three central components: funds for education or training and funds to provide for living expenses while there; significant loan guarantees for homes and businesses; and up to one year of unemployment pay. ${ }^{196}$ Upon signing the GI Bill into law, the president emphasized other aspects of the bill, namely the establishment of hospitals and more centralized authority for the VA to quickly grant these benefits. Even though the GI Bill was promised to all but those discharged dishonorably, by 1945, VA policy specifically denied benefits to soldiers who received undesirable or administrative discharges "because of homosexual acts or tendencies." 197

\section{Unequal Treatment}

Henry Gerber had reenlisted with the Army primarily for financial reasons in 1925 and would serve into World War II. ${ }^{198}$ Gerber's pension from his service in the occupation forces after World War I barely covered his expenses, and although he carefully budgeted himself, he realized that reenlistment and an eventual discharge for medical disability could multiply his pension's value and entitlements. ${ }^{199}$ Even while in the Army, he continued to be an activist, writing letters and essays to magazines. Under the penname Parisex, he criticized writers who claimed gay people avoided military

\footnotetext{
${ }^{195}$ Canaday, 144.

${ }^{196}$ U.S. Department of Veterans Affairs, "About GI Bill: History and Timeline."

${ }^{197}$ Canaday, 138.

${ }^{198}$ Sears, 73.

${ }^{199}$ Gilgamesh et al.
} 
service or social responsibility, writing as a serviceman, "I am not aware of their having been exempted in the late war." ${ }^{200}$ While some gay draftees and volunteers were turned away or discharged early in their careers, others like Gerber relied on what some gay men referred to as "the ignorance and naiveté of the American public." ${ }^{\text {201 }}$ He had spent the first months of World War II escorting draftees between Baltimore and Chicago when he was questioned by an army psychologist because of inquires raised by his record. When asked if he was a homosexual, Gerber responded honestly that he only participated in mutual masturbation with men, to which he was told, "then you're not homosexual.",202 Gerber was amazed at the apparent ignorance of the psychiatrist, did not insist on his sexuality, and was cleared to continue serving until his honorable discharge in $1942 .{ }^{203}$ Receiving veterans' benefits for his service in World War II allowed Gerber to live at a veteran's hospital in Washington D.C., where his room and meals were paid for, and his new pension was roughly five times what it had been when he first left the military. The ability to collect veteran benefits took care of his most important expenses for the rest of his life and millions of other veterans would receive similar benefits.

Whereas Gerber's continued service appeared to be on account of a psychiatrist's ignorance of homosexuality, other military psychiatrists purposefully helped gay soldiers. Bertram Schaffner was a screening physician for new recruits, and knew firsthand that

\footnotetext{
${ }^{200}$ Parisex (Henry Gerber), "In Defense of Homosexuality (1932)," In Mark Blasius and Shane Phelan, eds. We Are Everywhere: A Historical Sourcebook of Gay and Lesbian Rights (New York, NY: Routledge, 1997), 220-221. (Hereafter We Are Everywhere)

201 Chauncey, 103.

${ }^{202}$ Gilgamesh et al.

${ }^{203}$ Gilgamesh et al. Gerber's reaction was described as: "I nearly fell off the damn stool. Here this jackass is telling me I'm not homosexual and I've been arrested three or four times, I spent all my life trying to organize homosexuals even through I've pretty much given up any hope that its possible, and I've been blackmailed five or six times, and he tells me that I'm not homosexual. And I just have to nod and be agreeable because I want that pension."
} 
there were other gay men like himself who wanted to serve and that they would not be a burden to the military. When he encountered patriotic recruits who were gay, he accepted them into service and ensured nothing in their file related to homosexuality would bar them from serving their nation. ${ }^{204}$ When he met with recruits whom he thought would break down or be a burden, Schaffner "would discharge them, but I would always try to find another diagnosis so they could be medically, honorably discharged." ${ }^{205}$ He had felt that it was his professional responsibility not expose a patient to humiliation or public harassment:

I thought, as a doctor, my obligation was not only to take care of the Army, but as a doctor I also felt I had a duty to the people going through. After all, if I were to learn certain secrets which I was forced to get, and which they were forced in a way to tell, I didn't think it was fair for them to be scarred for life and to be in disgrace and to have the community know things about them that they didn't need to know. ${ }^{206}$

His concern appeared warranted provided that veterans were required to report to their draft board upon being released from service. At the draft board, the status of and reason behind a soldier's discharge were not confidential, thus the status of a gay soldier was immediately known by their community. All future employers, schools, financial companies, and veterans' organizations had access to such information and could discriminate against them. ${ }^{207}$ Bérubé described how the public discrimination and humiliating nature of such discharges as the results of an intentional military decision to stop "masses of well-adjusted gay soldiers and heterosexual malingerers" from confessing to homosexuality to avoid the draft and the responsibilities of service. ${ }^{208}$

\footnotetext{
${ }^{204}$ Schaffner, Segment 92.

${ }^{205}$ Schaffner, Segment 91.

206 Schaffner, Segment 89-90.

207 Bérubé, 229.

208 Bérubé, 229.
} 
Similarly, historian Naoko Wake found that the psychiatrists who developed military screening practices between 1939 and 1942, targeted men who were "unfit" for service, were aware that exclusion from the army was a major social stigma and could seriously damage the mental health of their patients. ${ }^{209}$ At the same time, army recruiters increasingly investigated the public reputation of female applicants and sought to bar those who were known for promiscuity with men or had more general homosexual tendencies. Recruiters were instructed to question the motives of women that applied in order to determine if they were motivated by patriotic ambitions, or instead wanted to "be with other girls," in an attempt to uncover "questionable" and unwanted sexual or romantic attitudes among female applicants and recruits. ${ }^{210}$

Psychiatrists felt that the most accurate way to diagnose the personality and conditions of any recruit would be through careful, in-person interviews. ${ }^{211}$ Yet, this was not feasible as military induction staff like Schaffner described having only two or three minutes each to examine and speak to hundreds of recruits a day. ${ }^{212}$ Factors like extended exposure to combat, the loss of friends, and the loss of confidence in commanding officers were able to affect the mental health of any soldier despite the best efforts of the military to screen out certain types of people. At one point in the war, one quarter of military hospital admissions were due to neuropsychiatric disorders. This led to a 1944 report by John W. Appel and Gilbert W. Beebe that concluded that some psychiatric casualties, like shellshock in World War I, were inevitable. Appel and Beebe still wanted

\footnotetext{
${ }^{209}$ Naoko Wake, "The Military, Psychiatry, and "Unfit" Soldiers, 1939-1942." Journal of the History of Medicine and Allied Sciences 62:4 (2007): 463.

${ }^{210}$ Meyer, 157.

${ }^{211}$ Wake, 475 and 486.

${ }^{212}$ Schaffner, Segment 88.
} 
induction screening, but also insisted on faster and accurate diagnosis at the frontlines. ${ }^{213}$ When President Roosevelt referred to veterans" "special problems," VA veteran care would have to treat both physical and mental injuries.

Paul Hardman, who served from 1940 to 1946, believed that the military was "an advantage for both men and women to get an education, if it may be the only way. You can get much more than that because the opportunities are endless." ${ }^{214}$ However, while praising the benefits of military service for young Americans, Hardman firmly believed it was not possible to simultaneously be gay and be a soldier, saying decades after his own service that "you must give up your gay self to do it [serve]." ${ }^{215}$ Schaffner, as he hid gay recruits from commanders and helped discharged gay servicemen avoid discrimination from their hometowns and future employers, appeared to exemplify this balancing act of being gay and being patriotic in World War II. "I knew that I was not obeying army regulations. But after all, in wartime, you have to do a lot of things that you might otherwise think are illegal. All's fair in love and war." ${ }^{216}$ Schaffner himself would be deployed to a psychiatric triage unit near the front lines in France. He was a major by then, but as a medical officer, he carried no weapon even when traveling to Bastogne during the Battle of the Bulge. ${ }^{217}$ But despite his bravery and commitment to service, if his sexuality were to have been discovered, he would have likely been court martialed. ${ }^{218}$

\footnotetext{
213 Wake, 492.

${ }^{214}$ Hardman, in My Country My Right to Serve, 27-28.

${ }^{215}$ Hardman, in My Country My Right to Serve, 27-28.

216 Schaffner, Segment 93.

217 Schaffner, Segment 96.

${ }^{218}$ For more about Dr. Schaffner's life and career see: Susan Cousins Breen, "Beyond the Emotional Turmoil: Gay Psychiatrist Bertram Schaffner '32 Brings Compassion and Dignity to His Homosexual Patients," Swarthmore College Bulletin (Blog), Swarthmore College, October 2009. Jeffery Langham, "Remembering Gay Pioneer Bertram Schaffner," Through Testimony (Blog), USC Shoah Foundation, June $7,2016$.
} 
This was the case for thousands of gay service members, regardless of rank or achievement.

\section{Navigating New Rules}

In 1943 alone, the Army discharged 1625 soldiers for homosexuality. ${ }^{219}$ At the start of World War II, soldiers discovered to be gay were typically sentenced to jail time. However, as the draft expanded and the number of inductions increased by the millions, the Judge Advocate General's Office and high ranking officials in various military branches saw a significant strain on the ability of the armed forces, especially in the Army, to investigate, court martial, process, and imprison every soldier who allegedly committed homosexual acts. In fact, in November 1942, Army Chief of Staff George C. Marshall criticized commanders that relied on courts martial to enforce discipline because it showed a "lack of leadership and faulty command."220 By January 1943, sodomy was still a crime, but there was an exception to deal with so-called "confirmed perverts" that did not use force or violence to commit sodomy. Instead of a court martial, a board of officers would review and discharge that soldier. ${ }^{221}$ According to Bérubé, some generals compared homosexuality to a mental or physical health issue, an issue for health professionals rather than a prison, and chose to only discharge soldiers they believed to be gay because it did not require the effort of a trial. ${ }^{222}$

These administrative discharges were frequently employed to quickly remove soldiers from active service. ${ }^{223}$ Section Eight of Army Regulation 615-360 famously

\footnotetext{
${ }^{219}$ Fred L. Borch III, “The History of “Don’t Ask Don’t Tell” in the Army,” Military Law Review 203 (2010): 194.

${ }^{220}$ Bérubé, 135.

${ }^{221}$ Hamph 21.

222 Bérubé, 129.

${ }^{223}$ Canaday, 145-146.
} 
became known as a "blue discharge," named for the color of the paper on which they were printed. This type of discharge was used to remove soldiers with "undesirable habits or traits of characters" from service and included "sexual psychopaths." 224 They were reserved not only for soldiers accused of homosexuality, but included a wider variety of soldiers who the military did not want within the ranks, such as African American soldiers who challenged segregation, drug addicts, alcoholics, and people with other psychiatric conditions. ${ }^{225}$ Similar to American metropolitan cities earlier in the century, authorities frequently found it easier to prefer lesser charges to gay men and women, because real trials often required more time and evidence. Yet even these lesser charges, misdemeanors, and undesirable discharges had effects which followed gay men and women throughout American society.

In January 1944, War Department Circular No. 3 revised and finalized previous anti-homosexual policies within the armed forces. For the rest of the war, gay service members, including "latent homosexuals," were to be hospitalized and interviewed, even if they had never committed any homosexual acts. ${ }^{226}$ At the end of March 1944, Herbert wrote to Doyle again. Herbert had been on furlough earlier in the year and was catching up on military policy updates.

The enclosed is a War Department Circular I found today. Was reading all the ones I've missed on furlough + naturally was most interested in this one. Here is the definite information you've been wanting. The copy is exact. One thing though, it [the circular] most definitely doesn't define the terms which gives it ambiguity or leeway in some respects. They say what shall be done but don't

\footnotetext{
${ }^{224}$ Hamph, 21.

225 Canaday, 146.

${ }^{226}$ Hamph, 20-21. The work of Sigmund Freud had popularly described a latent homosexual as a person who had gay "impulses that remain repressed so that they never come to consciousness but continue to exercise an influence on the individual's mental processes." In the context of the American armed forces, the "latent homosexual" further included any man or woman who was reported for, or confessed to, homosexual tendencies even if they never committed a chargeable offense.
} 
really come to grips with the issue - that is - actually being seen- dear say ek- as grounds for it. What are your thoughts on the matter? ${ }^{227}$

One update she noticed and sent to the woman she loved, but did not explicitly say what the update was in the letter, only implying it concerned them. ${ }^{228}$ It appears certain that this letter was Circular 3.

The new ruleset attracted the attention of gay soldiers who realized more than ever they had to hide their personal lives. Letters from this time between Doyle and Herbert no longer explicitly describe their mutual attraction, and they were right to be concerned as other servicewomen faced the new discharge rules. In May 1944, after a WAC private's mother read and reported mail her daughter received, an investigation was launched by the military into the relationship between the WAC private and sergeant. In that investigation, their letters were used as evidence and reportedly contained "professions of passionate love, of jealousy, of longings for each other and suggestive references."229 Similarly, when a Corporal Kellog and Second Lieutenant Warren, both WACs, were placed under investigation, they both admitted to having a relationship. The lieutenant, despite being younger by five years, aimed to protect Kellog by testifying that as a commanding officer she had "seduced" the "kid." 230 She had successfully convinced the discharge board that their relationship was Kellog's first such experience and, therefore, could return to service after psychiatric evaluation and treatment.

This was another tool that War Department Circular No. 3 emphasized, gay service members were to be discharged unless they supposedly could be cured. Officers

\footnotetext{
${ }^{227}$ Esther Herbert to Marvyl Doyle, 29 March 1944, Box 1 Folder 3, Herbert and Doyle Collection.

${ }^{228}$ Esther Herbert to Marvyl Doyle, Herbert and Doyle Collection.

${ }^{229}$ Hamph, 24.

${ }^{230}$ Hamph, 25.
} 
were "offered the opportunity and [permission] to resign for the good of the service" while enlisted personnel were to be discharged "without honor."231 Warren assumed the blame of having turned Kellog to a lesbian relationship and was given the offer to resign while Kellog was sent to psychiatric treatment rather than being dishonorably discharged. However, that resignation was still a form of administrative discharge and did not entitle her to veterans' benefits. ${ }^{232}$

Bertram Schaffner recalled clear policy directing the discharge of gay men as to "not to get any of the benefits of having served military service." ${ }^{233}$ Even so, if a soldier had served the required amount of time and was not charged with a crime, but did face administrative penalties or discharge, Congress had determined in 1944 that "such offense should not bar entitlement to benefits." ${ }^{234}$ This was evidenced by the language of the GI Bill which said it would provide benefits to all but dishonorable discharges. However, the VA had permission to determine if a blue discharge was given under honorable or dishonorable circumstances. Being gay was designated as dishonorable and even those who avoided dishonorable discharges would face VA discrimination. The discrimination against discharged gay soldiers was immense and emphasized that they were either dangerous or totally incapable of being legitimate soldiers.

Staff Sargent John McPherson was an Army quartermaster in 1944. He had been in the army for 46 months and he described his accomplishments thusly: "I wore a Good Conduct ribbon. I also had a half-dozen majors' affidavits and recommendations for Officer Candidate School in my files... which said my character was excellent. My

\footnotetext{
231 Borch, 194.

232 Hamph, 25.

${ }^{233}$ Schaffner, Segment 89.

${ }^{234}$ Canaday, 146.
} 
company records carried me as fit for duty." ${ }^{, 235}$ But then he was reported for allegedly touching another soldier on the shoulder and complimenting his appearance. He was detained, questioned, handcuffed once he admitted to being gay, and then was put into solitary confinement for the night. On February 25, 1944, just short of four full years of service, McPherson was no longer a soldier. He was left in front of his base in civilian clothes, with blue discharge papers that labeled him as having poor health, poor character, and designated him as 4F for the draft despite originally being $1 \mathrm{C}$ when he enlisted. He stated that his time in service was described on-paper as an error, that those papers said he never wore a uniform. None of his commendations mattered and he was never allowed to wear any medal or ribbon he had been awarded. McPherson recalled that "I was entitled neither to mustering-out pay nor to a discharge pin."236 Bérubé described similar stories of soldiers given a blue discharge. Some were relieved of their ranks, medals, and uniform. Army authorities often forced gay discharged soldiers to exchange their uniforms for civilian suits and a bus ticket home. One such soldier, Stan Carlow had a near exact experience as McPherson. His Coral Sea badge was taken away from him at Fort Lawton in Washington and he was told he would face federal prison if he ever attempted to serve in uniform again. ${ }^{237}$ To be gay meant one's service was illegitimate in the eyes of the military, the public, and more importantly, the VA.

\section{Leaving World War II, Only Partially a Veteran}

There was such significant discrimination for purged, gay veterans that soldiers who did not receive honorable discharges, even if they were not gay, frequently worried

\footnotetext{
${ }^{235}$ McPherson, in My Country My Right to Serve, 32-33.

${ }^{236}$ McPherson, in My Country My Right to Serve, 35.

237 Bérubé, 229.
} 
that they would have to explain their circumstances or face stigma in employment as if they were. ${ }^{238}$ John McPherson described that, despite nearly four years of perfect service, “Legally, I'm only partially a veteran. The first time I went into a Veterans'

Reemployment Office, I practically got thrown out and was told I had no right to set foot inside the door." 239 The VA initially was granted some leeway in interpreting the GI Bill's beneficiaries. In 1944, they notably interpreted the GI Bill in accordance with definitions of honorable service, found in the 1924 World War Veterans' Act. Rather than restricting GI Bill benefits from only dishonorable discharges, the VA interpreted any general or administrative discharge for "moral turpitude" the same as a dishonorable discharge. Because of the language of the GI Bill and the different interpretation by the VA, local VA offices across the country did not equally apply benefits to veterans with blue discharges. This despite the fact that the 1924 law predicated such disqualification on a court conviction, while blue discharges notably had no court involvement. ${ }^{240}$ In 1945, the VA created a nationwide policy explicitly stating that all discharges for homosexual actions or tendencies were to be considered dishonorable. ${ }^{241}$

After the war, the revolutionary effects of the GI Bill were apparent. The VA backed more than two million home loans before 1952. By 1947, veterans accounted for forty-nine percent of college admissions across the country, and by 1956 more than 7.8 million of the 16 million World War II veterans had used VA services to gain access to education and training programs. In fact, according to the VA, the least-utilized aspect of

\footnotetext{
${ }^{238}$ Canaday, 148.

${ }^{239}$ McPherson, in My Country My Right to Serve, 34.

${ }^{240}$ Canaday, 149.

${ }^{241}$ Canaday, 150.
} 
the GI Bill was its unemployment benefits. ${ }^{242}$ But thousands of gay soldiers were not allowed access, and this active prejudice extended deeper into American society with the coming Cold War.

${ }^{242}$ U.S. Department of Veterans Affairs, “About GI Bill: History and Timeline.” With the investments in the future homeownership and education, such disparities between the numbers of veterans utilizing educational programs and those requiring unemployment aid suggest that the GI Bill not only paid for major expenses, but ensured that veterans could return to gainful opportunities in the postwar economy. 


\section{Chapter 4: The Cold War}

In his speech upon signing the GI Bill, President Roosevelt ended by saying, "A sound postwar economy is a major present responsibility."243 With World War II over, many Americans returned home to an era of prosperity and opportunity. This was the case for seemingly all Americans, and Elaine Tyler May has described the postwar United States as advertising itself as unified, affluent, and in political harmony. ${ }^{244}$ But the 1940s and 1950s were also a time where anxiety and fears over national security often overshadowed issues of civil liberty and due process. Christina Jarvis notes that, by 1944, the prevailing mood was "never again must America be caught unready to go to war at the drop of the hat." 245 The fear of enemies beyond and within American borders led to mass dismissals of gay Americans from the government and military. For Andrea Friedman, the new "age of McCarthyism" existed in a "state of exception" that was the threat of future war with communist nations. ${ }^{246}$ It was in this early decade of the Cold War that many gay men and women within the United States created lives and careers, only for many to lose those same opportunities.

The Red Scare

Joseph McCarthy was a Marine Corps major in World War II before becoming a U.S. senator from Wisconsin in 1947. As a politician, his name was synonymous with tough anti-communist action at home. The Red Scare gained its power through the willingness of leaders in both private and public institutions to condone the limiting of

\footnotetext{
${ }^{243}$ Roosevelt.

${ }^{244}$ May 8.

245 Jarvis, 72.

${ }^{246}$ Andrea Friedman, Citizenship in Cold War America: the National Security State and the Possibilities of Dissent (Amherst, MA: University of Massachusetts Press, 2014), 6-7.
} 
American civil liberties in exchange for national security. This sense of security was derived from the elimination, and containment, of perceived communist threats. ${ }^{247}$ Historian Stephen Whitfield described McCarthy's perceived world as a paranoid one, where "failures of foreign policy were not due to misjudgment, contingency, ignorance, or error but to deliberate disloyalty." 248 When communist forces succeeded in China in 1949, opponents of Truman, like Senator McCarthy believed that the president and his policies were responsible for communist successes, and that Congress would need to oversee their own investigations into the loyalties of government employees. ${ }^{249}$ They insisted that only through public trials and intense scrutiny would the threat of communist government workers be contained. By February 1950, McCarthy publicly claimed he had a list of either 205 communists or 207 security risks who were presently employed in the State Department. Yet, when asked to present the list during an airport press conference, McCarthy told reporters that he left the list in a suit jacket's pocket on the plane and did not have it at that exact moment. ${ }^{250}$ The exact numbers of accused government workers, regardless of if they were communists or not, were not as important for him as was public perception. Before McCarthy even made his famous accusations, one third of Americans already thought that any member of the Communist Party should be jailed. ${ }^{251}$ But throughout the 1950s, this anti-communist fervor only appeared to increase. Whitfield wrote that many of the claims McCarthy made were guided less by evidence and more by

\footnotetext{
${ }^{247}$ Ellen Schrecker, Many are the Crimes: McCarthyism in America (Boston, MA: Little, Brown and Company, 1998), xi.

${ }^{248}$ Stephen J. Whitfield, The Culture of the Cold War (Baltimore, MD: The Johns Hopkins University Press, 1996), 37.

${ }^{249}$ Kaiser, 68.

${ }^{250}$ Erwin R. Bayley, Joe McCarthy and the Press (Madison, WI: The University of Wisconsin Press, 1981), 20.

${ }^{251}$ May, 12.
} 
his "sense of what would inflame his followers and snare the headlines." ${ }^{252}$ Indeed, more was to come.

During a radio interview in Salt Lake City, Senator McCarthy stated that he "had the names of 57 card-carrying members of the Communist Party," and that the Secretary of State, who publicly denied such an allegation, was functionally blind to clear "cardcarrying" traitors in his midst. ${ }^{253}$ But Congress members like Senator Styles Bridges (R$\mathrm{NH}$ ) believed no one, much less his ally McCarthy, would be able "to prove there was one card-carrying Communist in the State Department.” Instead, Senator Bridges publically called on Senator McCarthy to seek out "bad security risks" that Congress believed to be just equally detrimental to national security. ${ }^{254}$ McCarthy would say later that traitors, in his view, did not actually have to be communists or even allied with them. He said in a 1950 interview with Meet the Press that the communist threats were obviously not even card-carrying members of the Communist Party, but were really "those men who are doing the job that Communists want them to do." ${ }^{255}$ This chapter of the Red Scare sought out communists as well as anyone McCarthy and his allies believed did not belong in government. According to the Wisconsinite's claims, all such people were assuredly the same threat to national security as committed enemy agents.

Anti-communist rhetoric frequently focused on American "strength" and abhorred "softness," frequently linking excess comfort or deviance from societal norms as

\footnotetext{
${ }^{252}$ Whitfield, 37.

${ }^{253}$ Bayley, 20-21. The Senator changed his target accusation multiple times, even the famous " 57 cardcarrying" Communists was reduced to a broad " 57 cases of individuals who would appear to be either cardcarrying members or certainly loyal to the Communist Party, but who nevertheless are stull helping to shape our foreign policy."

${ }^{254}$ Johnson, 23. Senator Bridges said in one speech, "A man doesn't have to be a spy or Communist to be a bad security risk. He can be a drunkard or a criminal or a homosexual."

${ }^{255}$ Whitfield, 38.
} 
susceptible to Communist control. ${ }^{256}$ When Richard Nixon ran to be a California senator in 1950, he faced Helen Gahagan Douglass, a Democrat who he called "the pink lady." Earlier that year, Nixon had accused Truman's Secretary of State of having a blindness for the color pink, implying there were communists among the Secretary's friends and colleagues. In that Senate race, Nixon attacked Douglass's congressional record by calling it the "pink list" which implied that Douglass consistently showed communist sympathies, and describing her as "pink right down to her underwear." ${ }^{\text {257 }}$ Carrying nearly sixty percent of the vote, Nixon won. Once in the U.S. Senate, Nixon politically weaponized the color pink to mean both a symbol of communist sympathies, but also of femininity and softness. In the process, politicians "used all the power of the state to turn dissent into disloyalty and... drastically narrowed the spectrum of political debate."258

\section{Different From the Others}

The gay service members of World War II were children of the Great Depression and many expected the government to provide social welfare programs. ${ }^{259}$ With the benefits of the GI Bill, they could assimilate and settle down as civilians. But after the war, anti-gay laws and government policies frequently clashed with the goals of living a secure and stable life. ${ }^{260} \mathrm{Hal} \mathrm{Call,} \mathrm{a} \mathrm{gay} \mathrm{veteran} \mathrm{and} \mathrm{activist,} \mathrm{wrote} \mathrm{that} \mathrm{World} \mathrm{War} \mathrm{II}$ exposed him and others to different lifestyles and cultures such that "at the end of the war they didn't want to go back to Aida, Oklahoma or Paducah, Kentucky! The world was enlarged for all of us."261 Gay veterans like Call often did not return to their hometowns

\footnotetext{
256 May, 12.

${ }^{257}$ K.A. Cuordileone, Manhood and the American Political Culture in the Cold War (New York, NY: Routledge, 2005), 45.

${ }^{258}$ Schrecker, $\mathrm{x}$.

${ }^{259}$ For more on the development of social welfare programs during this period, see Canaday.

260 Bérubé, 257.

${ }^{261}$ Sears, 103.
} 
after World War II, instead choosing to move to cities. ${ }^{262}$ Although heterosexual marriage was a way for gay Americans to assimilate and not draw attention, being 'happily' married did not fully protect some gay Americans, and the anxiety of exposure and arrest hung over the daily lives of many. When exposed as having homosexual inclinations to their neighbors and community, by arrest or rumor, the gay or bisexual husband or wife felt ostracized and knew they were never able to live domestic life in the same comfort as before, even if neighbors never talked directly about their sexuality. ${ }^{263}$

Historian Craig Loftin has described gay men and women in the Cold War as wearing a mask of heterosexuality and conformity, "to survive each day while they searched for, and increasingly found, one another."264 Gay men and women also participated in the Baby Boom and created families of their own. Because women were expected to raise children, divorced or unmarried lesbians often raised children with their partners in same-sex households, but gay men could not do the same until decades later. ${ }^{265}$ The typical suburban home was built for nuclear families, May explained, and single men and women were not able to access the suburban lifestyle. Divorcees and single people frequently faced a social stigma in the suburbs that characterized them as not true adults or as unable to properly contribute to Cold War society. ${ }^{266}$ As such, some gay and bisexual men felt that, "if you were a good man you went to college, you got a good job and in the meantime you get married and had kids... That's what I thought

\footnotetext{
262 Bronski, 168.

${ }^{263}$ Daniel Winunwe Rivers, Radical Relations: Lesbian Mothers, Gay Fathers, \& Their Children in the United States since World War II (Chapel Hill, NC: The University of North Carolina Press, 2013), 22.

${ }^{264}$ Loftin, 223.

${ }^{265}$ Rivers, 12. Lesbian and bisexual women could easily end up with a child through a previous sexual relationship with a man or even a one-time encounter, and could live with other women and raise children without much public attention. Gay and bisexual men did not have the same possibility.

266 May, 15.
} 
everybody should do." ${ }^{267}$ There was intense pressure by families and American society at large for people to marry and create families, and this pressure did not stop upon reaching gay Americans.

It was through the development of new communities after World War II that in 1947, an RKO Pictures secretary, going by the penname Lisa Ben, used her workplace access to a carbon copy machine to print and distribute a magazine titled Vice Versa, which included short stories and reviews of lesbian books. Although she only published a few issues, the magazine connected her to a community where she met dozens of other gay women and made new friends. ${ }^{268}$ By 1953 , a new magazine began to circulate within the gay community of Los Angeles, ONE: The Homosexual Viewpoint, published by ONE Inc. For many it represented a national "voice in the darkness," even despite censorship attempts and an American culture of suppressing dissent and difference. ${ }^{269}$ One reader praised the staff of $O N E$ as courageous, then lamented that they had not known about $O N E$ before a friend committed suicide, wishing that "she had felt that there was some slim chance of one day being both understood and accepted."270 Two years after $O N E$ published its first issue, the Mattachine Society followed suite and began to publish the Mattachine Review in 1955. Then in 1956, the lesbian-focused The Ladder began its distribution. ${ }^{271}$

\footnotetext{
${ }^{267}$ Rivers, 13.

${ }^{268}$ Marcia M. Gallo, Different Dauthers: A History of the Daughters of Bilitis and the Rise of the Lesbian Rights Movement (Emeryville, CA: Seal Press, 2007), xxxiii-xxxv. Sears, 115.

${ }^{269}$ Loftin, 18.

${ }^{270}$ Letters to ONE, 134.

${ }^{271}$ Joanne Meyerowitz, "Sex, Gender, and the Cold War Language of Reform," in Rethinking Cold War Culture, ed. Peter J. Kuznik and James Gilbert, (Washington, DC: Smithsonian Books, 2010), 113.
} 
The Mattachine Society

The widespread publicity of Dr. Alfred Kinsey's research in 1948 inspired people like Harry Hay to organize, realizing that millions of gay people could create and represent an "organizable minority." ${ }^{272}$ Members of the Mattachine Foundation, later called the Mattachine Society, were committed to unifying, educating both the public and other homosexuals, and fighting legal battles for acceptance as a new American minority. ${ }^{273}$ Hay was such an organizer, and had been an active member of the Communist Party into 1951, but left the Party that year due to its anti-gay rhetoric. ${ }^{274}$ Unsurprisingly, Hay's connection to the Communist Party left him vulnerable, especially as Cold War culture and politicians increasingly conflated homosexual acts with national security threats. ${ }^{275}$

In 1953, the Mattachine Foundation gained a burst of publicity by funding the legal battle of Dale Jennings, who detailed his story in the first issue of $O N E .{ }^{276}$ Newer members worried that association with Hay's Los Angeles branch would cost the rest of the organization because, "our association of the Mattachine with former communists would make us communist sympathizers." ${ }^{277}$ For every radical voice that supported Hay, there were a dozen other gay men who thought the House Un-American Activities Committee was asking good questions in hearings or were supportive of the war against

\footnotetext{
${ }^{272}$ Sears, 114.

273 Sears, 152.

${ }^{274}$ At first, this connection was not a problem for the early Mattachine Foundation as, to be gay was already largely illegal. As such, the Mattachine Foundation operated in small, independent cells across Southern California. At the same time, historian James T. Sears described the early Mattachine Foundation as a "group of lovers and former lovers," who "set homosexual organizing in motion." Sears, 118. Bronski, 79. Gallo, xxxv.

${ }^{275}$ Meyerowitz, 113.

276 Dale Jennings, “To Be Accused, Is to be Guilty,” ONE (January 1953), 10.

277 Sears, 152.
} 
Communist threats in Korea. ${ }^{278}$ Both liberal and conservative gay men wanted a greater voice in the now-growing Mattachine, and at their lead, Hal Call wanted to add to Mattachine's preamble that homosexuality required a free society to gain acceptance, that Russia was restrictive of personal freedom, and that "both the extreme right and extreme left, have been the most bitter enemies of the homosexual."279 As publicity brought attention and members, anti-communists worked to gain control of the whole Mattachine Foundation, forced Hay out, and rebranded as the Mattachine Society. ${ }^{280}$

\section{ONE: "Well You Need A Magazine."}

In 1953, ONE published its first magazine as an openly homosexual publication in Los Angeles. The magazine was conceived a year earlier when a group of gay men and women in Los Angeles attended a discussion group where a former vice officer discussed entrapment tactics used by police. By the end of the night, the audience was amazed at how little they knew about the law and entrapment tactics. Some people in the group were members of the Mattachine Foundation and wanted to get information about gay legal rights public, then someone said "Well you need a magazine." 281 The first issue would discuss court cases, debate within the California state assembly, and issue a call for letters and money. At first, the authors of ONE described their publication as "a youngster compared to such veteran publications as 'Die Insel'," a major German homophile publication, before noting "how similar are its purposes to ONE's and how

\footnotetext{
${ }^{278}$ Sears, 229.

${ }^{279}$ Sears, 207.

${ }^{280}$ Meyerowitz, 113. For more about the individuals involved in the reorganization of Mattachine and the debates within that change, see: Sears, Chapters 11, 15, and 16.

${ }^{281}$ Sears, 166-167. True to this inspiration, in the third issue of $O N E$, they published a comprehensive list of individual rights in case of arrest. Martin Block, Dale Jennings, and Don Slater (eds.), "Your Rights In Case of Arrest," ONE (March 1953), 16.
} 
international are all of our aims." ${ }^{282}$ Making a magazine openly for a gay audience, with issues specific to gay people at its core, had been a project attempted and started by many before, but $O N E$ had staying power. ${ }^{283}$ At its height, it had monthly viewership in the thousands and both a transnational and international audience. ${ }^{284}$

Some historians described $O N E$ as the more militantly homosexual of the two major gay publications, and that it refused to engage in the same anti-communist purges, whereas the Mattachine Review frequently reprinted an anti-communist disclaimer. ${ }^{285}$ Others like James T. Sears described that $O N E$ was critical of Hay, but also was critical of the more conservative leadership of Mattachine. ONE served as a center of debate for whether gay men and women represented a distinct American minority or not. ${ }^{286}$

\section{Daughters of Bilitis}

The Ladder was the flagship publication of the Daughters of Bilitis, founded in 1955 as a secretive lesbian social club in San Francisco. The name was an obscure literary reference whose meaning could be reinterpreted away from lesbianism, providing a public mask, from behind which women could balance visibility with safety. ${ }^{287}$ In the 1950s, as women felt compelled to create families and conform to certain American values, women employed in government offices had access to good-paying jobs that gave them an amount of economic mobility, and freedom that allowed them to avoid marriage

\footnotetext{
${ }^{282}$ A. E. Galbraith, "Die Insel." ONE (January 1953), 4.

${ }^{283}$ Sears, 168. Henry Gerber, Lisa Ben, and Jim Kemper all had brief attempts at creating magazines before the 1950s, gay military newsletters had been quickly stopped during World War II, and Manuel boyFrank pitched a similar idea in correspondence to friends before and after the war.

${ }^{284}$ Loftin, 17.

${ }^{285}$ Meyerowitz, 114.

286 Sears, 170

${ }^{287}$ Gallo, 20.
} 
and domestic motherhood. ${ }^{288}$ It was against this backdrop that the Daughters of Bilitis aimed to be a lesbian voice for social change and provide education to women that would, "enable her to understand herself and make her adjustment to society in all its social, civic, and economic implications." ${ }^{289}$ The Daughters were similar to ONE and the Mattachine Society in that they wanted to promote self-knowledge, self-acceptance, and public acceptance, but their focus would be on issues affecting women, a reoccurring blind spot for the other organizations. ${ }^{290}$ Of these three magazines, $O N E$ was the most popular, but all three shared articles, audiences, and ambitions.

"The Keystone of the Arch of Our Democracy."

In the Cold War, American families, embraced more traditional gender roles and few divorced, preferring stable home environment. The GI Bill and a steady economy promised housing, education, and success. With these benefits and comforts, according to May, the home "seemed to offer a secure, private nest removed from" the Cold War. ${ }^{291}$ At the same time, backyard shelters, air raid drills in school, private supply stockpiles, and communities vigilant towards outsiders underscored how every aspect of family was charged with notions of self-defense. According to Carolyn Herbst Lewis, medical concerns over sexuality and family health were direct reflections of Cold War rhetoric which emphasized the danger of "enemies within," while families represented "the keystone of the arch of our democracy."292 Whereas the Great Depression had broken

\footnotetext{
${ }^{288}$ Robert J. Corber, Cold War Femme: Lesbianism, National Identity, and Hollywood Cinema, (Durham, NC: Duke University Press, 2011), 17

${ }^{289}$ Gallo, 11.

${ }^{290}$ Gallo, 13. See also: J.P., "For Men Only?” ONE (August 1953). Some women did work for ONE and made critical contributions, but there was still a perception that women's views were missing. Sears, 176 (endnote 36).

${ }^{291}$ May, 1 and 15.

292 Lewis, 2.
} 
apart families and left many transient, the postwar era was its antithesis with widespread employment, education, and housing opportunities for Americans, particularly spurred on by the GI Bill. Large cities grew with their demand for a highly educated workforce, and new regions like Orange County in California and Colorado Springs in Colorado, grew with new homes for returning veterans and technological industries. ${ }^{293}$ Just as World War II sparked mass movement across regions and states, bolstering the populations of cities involved in wartime production, the Cold War era did the same.

Fractures on the Surface

American propaganda efforts, aimed at Europe and the Soviet Union, often depicted Americans as celebrating their diversity, socioeconomic mobility, and great political freedoms like voicing "their opinions without fear of reprisal."294 There was a common belief among American policymakers that "conflict within the United States would harm our image abroad, strengthen the Soviet Union, and weaken the nation, making it vulnerable to communism." 295 Some historians have noted that the idealistic World War II propaganda and rhetoric, which emphasized that the United States was at war with racist and totalitarian regimes, also highlighted the inequality within the American system for minorities, especially African Americans, hampering their

\footnotetext{
${ }^{293}$ For more on the postwar movement of Americans and the development of a technological and highly educated postwar economy, see: Ann Markusen, "Cold War Workers, Cold War Communities," in Rethinking Cold War Culture, ed. Peter J. Kuznik and James Gilbert, (Washington, DC: Smithsonian Books, 2010), 50.

${ }^{294}$ Laura A. Belmonte, Selling the American Way: U.S. Propaganda and the Cold War (Philadelphia, PA: University of Pennsylvania Press, 2008), 3-13. Belmonte described that such an image was necessary as in the years after World War II, American propagandists worried that "people in other countries think of us as the nation with the atom bomb, the B-29 [bomber] planes, the huge navy and air forces. The impression is liable to give rise to misunderstanding, fear, and hatred," then hoped their work on this new image would convince the world of the cultural and social strengths and appeal of American life. Belmonte, 13. ${ }^{295}$ May, 9.
} 
participation in the postwar economic successes. ${ }^{296}$ Segregation, Japanese American internment, the refusal to admit Jewish refugees, and riots in major American cities had already contradicted the narrative of American unity in wartime, even as Americans of all races and origins fought and died in the war with a hope for victory abroad and at home. ${ }^{297}$ With the war over, racial discrimination was still widespread in both the military and civilian life. ${ }^{298}$ But because the nation was segregated both racially and economically, the picturesque "good life" of stable suburban homeownership that came to represent the Baby Boom was often only accessible by the white middle and working class. ${ }^{299}$ At the same time, police activity and government purges forced many gay Americans to remain hidden or face threats to their careers.

Loyal Americans

Much of the early Cold War hinged on ideas of containment. Containment of communism in foreign wars like Korea, containment of the Iron Curtain's economic appeal with the Marshall Plan and foreign aid, and the containment of communism at

\footnotetext{
${ }^{296}$ Steve Estes examined the uphill struggle of African American civil rights from World War II to the 1970s. The reoccurring theme in this work was while both white and black American men held the same basic ideals and goals, Estes described that "Manhood entailed an economic, social, and political status ideally achievable by all men... racism kept many men, especially working class black men, from achieving these attributes of manhood." Steve Estes, I am a Man!: Race, Manhood, and the Civil Rights Movement (Chapel Hill NC: The University of North Carolina Press, 2005), 7.

${ }^{297}$ For more on racial inequality in World War II see: Ronald Takaki, Double Victory: A Multicultural History of America in World War II (New York, NY: Bay Back Books, 2000).

${ }^{298}$ Ronald Takaki identified many flashpoints for civil rights in the postwar-era including school and military segregation. This was even as "millions of men and women of different racial and ethnic minorities had challenged America's contradictions of the color lines, and in the process reinvented themselves." Ronald Takaki, A Different Mirror: A History of Multicultural America (New York, NY: Bay Back Books, 2008), 381. For more on the desegregation of the military see: Peter S. Kindsvatter, American Soldiers: Ground Combat in the World Wars, Korea, \& Vietnam (Lawrence, KS: The University Press of Kansas, 2003), Chapter 11.

${ }^{299}$ May, 2. For more on the enforced racial segregation of new suburban communities in Los Angeles see: George Sanchez, "'What's Good for Boyle Heights Is Good for the Jews': Creating Multiracialism on the Eastside during the 1950s," American Quarterly 56:3 (2004): 633-661. See also: Josh Sides, "Straight into Compton: American Dreams, Urban Nightmares, and the Metamorphosis of a Black Suburb," American Quarterly 56:3 (2004): 583-605.
} 
home all occupied American politics and seemingly united Americans. ${ }^{300}$ Historian K. A. Cuordileone found that American "liberalism... was barely distinguishable from conservatism," because of the unity behind anti-communist rhetoric and policies. ${ }^{301}$ Students, labor unions, lawyers, teachers, and even entertainers were expected to sign loyalty oaths, or they could end up blacklisted by their peers or subject to extreme professional and public scrutiny. ${ }^{302}$ The 1947 Executive Order 9835 created President Truman's Loyalty Review Boards along with a major national security infrastructure, in part to avoid legislative action in rooting out subversive government workers. ${ }^{303}$ Eventually, such reviews turned into trials before The House Committee on Un-American Activities (HUAC), which searched for communists and subversive Americans in federal government, state government, entertainment, unions, schools, and possibly any aspect of American life. ${ }^{304}$ The Loyalty-Security program operated behind closed doors, screening millions of government workers, including federal contractors, state and local government workers, and even corporate employees. The program threatened or convinced American workers to name potential accomplices to subversion with threats of job loss. Friedman wrote that the Loyalty-Security program exemplified "the threat posed by the cold war-era state of exception to the individual rights and economic opportunity that were supposedly at the heart of the American way of life." ${ }^{305}$ Instead of a criminal

\footnotetext{
${ }^{300}$ For more on American intellectual and political responses to Cold War containment, such as foreign aid, see: Michael E. Latham, Modernization as Ideology (Chapel Hill, NC: University of North Carolina Press, 2000).

${ }^{301}$ Cuordileone, 36 .

${ }^{302}$ Richard M. Fried, Nightmare in Red: The McCarthy Era in Perspective (New York, NY: Oxford University Press, 1990), 4.

${ }^{303}$ Fried, 68.

${ }^{304}$ Peter Filene, “'Cold War Culture' Doesn't Say It All,” in Rethinking Cold War Culture, ed. Peter J. Kuznik and James Gilbert, (Washington, DC: Smithsonian Books, 2010), 159.

${ }^{305}$ Friedman, 84.
} 
investigation, this was an administrative measure much like the discharge proceedings of the military, neither relying on official courts nor definitive evidence. Faced with these proceedings, many government workers resigned rather than face an administrative investigation that could cost their future career prospects or embarrass them publicly. ${ }^{306}$ Purged government workers found themselves subjected to economic and social repercussions, from being denied insurance coverage to former friends crossing the street to avoid passing them. ${ }^{307}$ By protesting war and nuclear arms, or by supporting civil rights or victims of the McCarthy hearings, historian Jane Sherron De Hart described how protestors faced "very real risks" just for challenging "the basic assumptions of [national] defense and racial policy." ${ }^{308}$ Playwrights and entertainers were called before congressional committees to explain their previous political affiliations and name members of their organizations, even if the connections were decades old. ${ }^{309}$ Some witnesses denounced the Senate hearings and called it a circus, invoked the Fifth Amendment, or believed it was antithetical to American values. Other witnesses though, like a cinematographer named Jerome Robbins implicated professionals he had known who had communist ties to the same organizations he had been a part of. As Robbins, explained, "I think I made a great mistake before, joining the Communist party, and I feel I'm doing the right thing as an American." ${ }^{310}$ In 1953, public polling found that while communism was the top fear of only twenty percent of Americans. At the same time,

\footnotetext{
306 Corber, 17.

307 Schrecker, 305.

308 Jane Sherron De Hart, "Containment at Home: Gender, Sexuality, and National Identity in Cold War America," in Rethinking Cold War Culture, ed. Peter J. Kuznik and James Gilbert, (Washington, DC: Smithsonian Books, 2010), 131.

${ }^{309}$ For more on the HUAC trials against the entertainment industry, and the response of entertainers to McCarthyism, see: Albert Wertheim, "The McCarthy Era and the American Theatre," Theatre Journal 34:2 (May 1982).

${ }^{310}$ Kaiser, 72.
} 
only twenty-nine percent of those polled were unsupportive of Senator McCarthy, but nearly fifty percent were supportive of his efforts. ${ }^{311}$ The reality was such that Americans widely believed that subversive individuals could, and would, infect and undermine the American body politic. The only way to protect the nation, the logic followed, was to find, investigate, and remove all such people from government positions and public life.

After the passage of Executive Order 9835, the Justice Department allowed the surveillance of members, correspondents, and associates of listed subversive groups, seeking any connection to communism. In one instance, Americans who perhaps visited a bookstore became the subjects of anti-communist investigations because it shared its mailing list with a communist organization. ${ }^{312}$ Early gay rights groups like the Daughters of Bilitis required that their members belong to no other organizations, in order to avoid suspicion under this surveillance, although the FBI still surveilled their membership and activities. Like them, the Mattachine Society and ONE Inc. were also surveilled by the FBI for decades. ${ }^{313}$

\section{The Lavender Scare: Stopping The Homosexual Viewpoint}

The border between the worlds of heterosexuals and homosexuals was not impassable, likely contributing to the Cold War fear of invisible deviations from societal norms, allowing many to live dual lives, both within and beyond American norms. If marriage, heterosexuality, and the creation of the nuclear family were emblematic of American strength in the Cold War, then homosexuality, which occurred outside of

\footnotetext{
311 Filene, 159.

${ }^{312}$ Fried, 70. Fried found that "membership in [such groups] might raise a question, but not conclusively prove disloyalty."

${ }^{313}$ Gallo, xvii, 1, 110. Johnson, 183. See also: Dal Mcintire, "Tangents: news and views," $O N E$ (November, 1960), 17. "For the first time in Mattachine history, a public discussion group has been raided."
} 
marriage and did not reinforce the nuclear family, was a threat to social order and cohesion. ${ }^{314}$ Throughout the Cold War era, lesbian and gay teachers would lose their jobs when their sexuality was discovered, for fear that they were likely to corrupt children. There was also a systemic fear of gay men and women raising children, because such a family structure, by its existence, would fundamentally undermine the construction of the purely heterosexual nuclear American family as both normal and necessary. ${ }^{315}$ The visible emergence of the American gay community following World War II appeared to align with popular fears that sexual depravity was a recent, corrupting development, but a containable one in much the same way communism was viewed. ${ }^{316}$

The post office acted as a tool of containment against homosexuality by preventing the spread of materials that postal inspectors believed were against the accepted culture of the United States. In 1950, the publishers and editor for From Here to Eternity had the author James Jones remove swears and many references to sex and homosexuality, for fear that the post office would block its distribution. Jones's daughter, Kaylie, explained, "if a book lost its mailing privileges, it had no way to reach its audience." 317 In much the same way, many were unsure if the magazine $O N E$ was even legal to circulate, and it would in fact face issues with distribution. The August 1953 issues of ONE were seized by postal authorities in both Los Angeles and Washington

\footnotetext{
314 De Hart, 126.

315 Rivers, 3.

${ }^{316}$ Corber, 12. In Cold War Femme, Corber describes how frequent film tropes about lesbians represented this fear. The butch archetype of lesbianism, a woman who seemed to emulate masculinity or reject traditional femininity, was often visible and identifiable to Cold War society, but the femme archetype was not. In fact, to be both a feminine and homosexual woman appealed to the Cold War concerns of invisible subversives and was identified by some as a way for homosexuality to pervert otherwise 'normal' Americans.

${ }^{317}$ Kaylie Jones, "Kaylie Jones : My Father, James Jones, and Censorship," Huffington Post, April 10, 2011.
} 
DC. After more than two weeks of examination, the post office determined that there was nothing obscene or illegal in the publication. ${ }^{318}$ A year later, in October 1954, ONE's editors aimed to publicly explain that what they published was reviewed by lawyers so that it could be considered safe for the mail; that issue was blocked by the post office for "obscenity." ${ }^{19}$ But when the U.S. Post Office blocked that issue of $O N E$ from being mailed on the charge of obscenity, ONE lost two federal appeals. The courts claimed that "an article may be vulgar, offensive, and indecent even though they are not regarded as such by a particular group... Social standards are fixed by and for the great majority," therefore, legally speaking, minorities like gay men and women were outside of 'normal' society. ${ }^{320}$ Even with that setback, by 1955, after just two years of publication, ONE was still available for purchase at stores in nine different cities across the United States, as well as in four cities outside of the country. ${ }^{321}$ The issue of mail inspection was a concern for one reader of $O N E$ from California, who sent a letter in 1955 to express his support of the magazine. He purchased issues of $O N E$ from a store but he and a friend, who was a World War II refugee, were concerned that if he ever subscribed for mail delivery "THEY might get a copy of the list." 322 The censorship of media that did not conform to

\footnotetext{
${ }^{318}$ Dale Jennings (ed.), "ONE is not grateful," ONE (October 1953).

319 ONE's Legal Counsel, "The Law of Mailable Material," ONE (October 1954). The editors and legal counsel of ONE believed that "lonely hearts ads," or messages seeking pen pals or meetings in person, erotic images, descriptions of sexual acts, fiction with physically intimate gay characters, or articles about sexuality where "the author encourages in others, or waxes too enthusiastic about" homosexuality were unprintable.

${ }^{320}$ Bronski, 201.

${ }^{321}$ Ann Carll Reid (ed.), "Where You Can Buy ONE,” ONE (January 1955).

The January 1955 issue of $O N E$ listed these cities: Amsterdam in Netherlands, Copenhagen in Denmark, Hamburg in Germany, Mexico D.F. in Mexico, New York City, Buffalo NY, Chicago IL, Cleveland OH, Minneapolis MN, Berkley CA, Los Angeles CA, San Francisco CA, and Salt Lake City UT.

${ }^{322}$ Letters to ONE, 36. Emphasis in original. In the context of this letter, "THEY" appeared to invoke a fear of Nazi-like surveillance, but is otherwise vague. The writer's desire to continue to read $O N E$ surpassed his fear, however.
} 
widespread ideas of morality was not new by the $1950 \mathrm{~s} .{ }^{323}$ In the end, ONE's appeal of the October 1954 issue eventually reached the Supreme Court in 1958, and the court ruled in its favor, citing the 1957 Roth v. United States which had redefined the standard of "obscene," and their Supreme Court appearance only garnered the magazine more attention. ${ }^{324}$

Like communism and the politically subversive, Americans in the early Cold War believed that if homosexuals barely differed from heterosexuals, and existed in all parts of American society, then they would certainly infiltrate cultural and political institutions and subvert them from within. ${ }^{325}$ Although many gay Americans wanted to make families, living a double life was not possible for some and they would move away from their families to live with a partner, rarely speaking to the family they left. This distance was rarely a choice as, in divorces and separations, if a judge discovered that one parent was gay, that parent would never be granted visitation rights claiming that the gay parent will "corrupt them [the children], you will damage them, you will do awful things.",326 Where international communism was expansionist and a military threat, domestic communism was seen as a type of infection, one that would fester and undermine the health of the nation if left unnoticed and untreated. ${ }^{327}$ For the American public,

\footnotetext{
${ }^{323}$ The Hays Office had complete influence over cinema, tasked with enforcing a law which required that "no picture shall be produced which will lower the moral standards of those who see it." Kaiser, 66.

${ }^{324}$ Bronski, 201.

${ }^{325}$ In popular entertainment, gay male characters were linked to the femme fatale. Like the femme fatale, explicitly gay characters were antagonists or dangerous, reflecting national security discourse of the time. Robert J. Corber, Homosexuality in Cold War America: Resistance and the Crisis of Masculinity (Durham, NC: Duke University Press, 1997), 11.

${ }^{326}$ Rivers, 30.

${ }^{327}$ Robert D. Dean, Imperial Brotherhood: Gender and the Making of Cold War Foreign Policy (Amherst, MA: University of Massachusetts Press, 2001), 67.
} 
regardless of who may or may not have a link to communism, homosexuality was perceived as a comparable source of moral or social corruption.

\section{The Lavender Scare: National Security}

Within the early Mattachine Society, rather than the behind-the-scenes leadership of founding members like Harry Hay, some members wanted an elected leadership. Such leadership would exclude communists from running as well as participating in the organization. ${ }^{328}$ For Call, distancing a former Communist like Hay from the organization he helped found made sense if they aimed for a national public image. "We would have been slaughtered off the bat if it was found out that we were organized by communists!" 329 This fear was well-founded given the realities of McCarthy's Red Scare which came to have a particular focus on gay Americans. In what became known as the Lavender Scare, gay Americans found themselves at the center of nationwide debates about their patriotism in the Cold War.

Whereas the Kinsey Report inspired Harry Hay to organize, Kinsey's claim that at least ten percent of men were gay struck fear in a culture where the popular belief was that gay men were both rare and easily recognizable. The Kinsey Report not only challenged the image of the nuclear family and heterosexuality as inherently normal, but exacerbated Cold War fears of hidden enemies. Historian Michael Bronski described that "this new, hidden homosexual could be lurking anywhere, in any male." 330 Rather than normalizing homosexuality, the public further stigmatized it and transitioned the paranoia of the Red Scare into the Lavender Scare. In the same timeframe, D. Milton Ladd, the

\footnotetext{
${ }^{328}$ Sears, 152.

329 Sears, 154.

${ }^{330}$ Bronski, 179.
} 
Assistant to the Director of the FBI, testified before Congress that "the Communists, without principals or scruples, have a program... to secure details of the private lives of Government officials, their weakness, their associates," with the goals to find an exploitable weakness in government employees and thus the nation. ${ }^{331}$ In this way, as early as 1948, magazines like Life described that the Communist Party of the United States "preyed upon intellectually precocious but sexually inadequate men" by using women and parties to attract and ensnare recruits. ${ }^{332}$ The idea that communists would sexually attract gay men, and blackmail them, appeared to be a logical step.Other American media similarly reported stories like "Lesbians Prey on Weak Women," where they stoked fears of lesbian conspiracies in both Americans schools and the military. ${ }^{333}$ Then, a Senate report lambasted government officials who overlooked the employment of gay people because they believed that what someone did in private and outside of the workplace was largely irrelevant to their employment. The report explicitly emphasized that such a "conclusion may be true with regard to the normal behavior of employees... but [the conclusion] does not apply to sex perversion." ${ }^{334}$ Even medical professionals weighed in on the patriotic strength of gay people, illustrated by a medical journal article by a physician named John Campbell in 1951. Campbell stated that while gay Americans could be "patriotic, loyal citizens," the fact they could be "blackmailed and browbeaten" made them great security risks. ${ }^{335}$ Roscoe H. Hillenkoetter, a Vice Admiral in World War II and the first director of the Central Intelligence Agency from

\footnotetext{
${ }^{331}$ United States Senate, "Employment of Homosexuals and Other Sex Perverts in the U.S. Government (1950)," 81st Congress, in We Are Everywhere, 245.

332 Dean, 70.

${ }^{333}$ Allan Berube and John D'Emillio, “The Military and Lesbians during the McCarthy Years," Signs 9:4 (Summer 1984), 760.

${ }^{334}$ United States Senate, in We Are Everywhere, 247.

335 Lewis, 4.
} 
1947 to 1950, explained that the blackmail of gay Americans would likely be successful because "homosexuality is universally condemned and actively attacked by the society in which the subject lives. ${ }^{״ 36}$ Despite this pervasive fear, historian Charles Kaiser found few known instances where gay Americans were successfully blackmailed into betraying their country. ${ }^{337}$ But the primary issue was that gay men and women could be blackmailed, not if they had been, and thus the primary concern of government employment purges. In this way, homosexuality and communism were theoretically linked in public discourse as they were both illegal and corrupting.

Letters and articles in ONE, like one by Elizabeth Lalo, emphasized that the mere accusation of homosexuality was enough to destroy one's life. In her experience, the threat to personal security was "enough to ruin a whole career, permanently smear a reputation and cause mental anguish resulting in suicide. ${ }^{" 338}$ In an early issue of $O N E$ Magazine, one lesbian government contractor described how the purges affected her. Miss E. M. was an aid worker in occupied Germany, working for a private agency under the authority of the State Department. Although gay, she had never encountered another lesbian personally, much less in a romantic or sexual way. Yet, there was a psychiatric record obtained by the State Department which said she was homosexual. Immediately, she was expelled from her work and sent home:

I was stunned and confused. The whole situation seemed like an evil dream. My plans for the future, my feelings of worthwhile accomplishment, and the work which had come to mean so much to me, were brought to an abrupt and cruel end.

\footnotetext{
336 Johnson, 111.

${ }^{337}$ Kaiser 80-81. In the one instance he did describe of such blackmail occurring, the victim, a columnist named Joseph Alsop, immediately reported the Soviet blackmail to his employers and the CIA. Alsop's statement was recorded, disseminated within the national security infrastructure, and then he continued his work.

${ }^{338}$ Elizabeth Lalo, “Must I Answer That Cop?” ONE (October 1953), 6.
} 
During the flight across the Atlantic, I could do nothing but cry. I felt completely alone and found it impossible to accept the reality of the situation. ${ }^{339}$

With no way to challenge her dismissal, Miss E. M. had to return to the United States, worried for her future and, perhaps more importantly, her personal ties. "I could not let my family and friends know this had happened." 340 By being gay, not only had Miss E. M. lost her livelihood in the name of national security, but she risked losing her family and community if the reason for her dismissal was discovered.

In 1953, President Eisenhower's Executive Order 10450 replaced the Truman-era loyalty program with one that emphasized the need for hiring and employee-retention to reflect national security interests and administrative power. These guidelines were based on the findings of earlier congressional reports that affirmed "sex perverts... violate moral codes and laws and the accepted standards of conduct," and due to said conduct they were both unsuitable for government service as well as being "security risks." 341 After Executive Order 10450, Richard M. Fried found that Congressional Republicans frequently publicized the numbers of dismissals under the program, even when the administration said that many dismissals were not security risks but were removed as a part of workforce reduction, further stoking fears of an unending number of infiltrators were in the government. ${ }^{342}$

The Lavender Scare: A Military Threat

Charles Schoen stayed in the Navy even after World War II ended. By the time he was the rank of petty officer in the 1950s, he was assigned to military intelligence where

\footnotetext{
${ }^{339}$ Miss E. M., “To Be Accused Is To Be Guilty: 2. The Ever-Present Past,” ONE (April 1953), 4.

${ }^{340}$ Miss E. M., 4.

${ }^{341}$ United States Senate in We Are Everywhere, 243.

${ }^{342}$ Fried, 133-134.
} 
he described being witness to not only the mass discharge of gay service members, but also the verbal and physical abuse of accused gay soldiers at the hands of brig guards. Being gay, he was afraid to report these events because "I still couldn’t jeopardize my own career by speaking out against those clowns [guards]. So I remained silent." 343 This scenario played out for many service members, even officers, who not only had to be closeted for the safety of their career, but also actively hunted and removed gay people from the military. ${ }^{344}$ In 1950, Congress replaced the Articles of War with the Uniform Code of Military Justice. Under the new UCMJ, every soldier had a duty to report any homosexual activities to commanders. The new rules also defined the punishments assigned to different violation classification levels and compelled commanders to court martial most violations. Writers in gay magazines described how the average American feared that gay people "run the risk of contaminating many hundreds of thousands of normal, healthy young men." 345 Going into the 1950 s, all military branches now had a unified set of rules and guidance that emphasized, "irrespective of sex," gay soldiers were not to be tolerated. ${ }^{346}$

Many thousands of Americans tried to serve and were denied any benefits of their service under the new UCMJ. In the late 1940s, a thousand gay men and women were removed from service each year for homosexuality, and twice as many in the 1950s. ${ }^{347}$ Looking at the threat of the ever-looming Cold War, gay activists in magazines like Mattachine Review questioned, "Are we so rich in manpower that we can afford to

\footnotetext{
${ }^{343}$ Schoen, in My Country My Right to Serve, 44. He continued to serve until 1963, eventually reaching the rank of Lieutenant Junior Grade, before he was also reported for homosexuality and given a dishonorable discharge.

${ }^{344}$ Faderman, 36.

345 James Fugaté, “Under Honorable Conditions,” Mattachine Review (May-June 1955), 42

${ }^{346}$ Borch, 195-196.

${ }^{347}$ Berube and D'Emilio, 760.
} 
discard thousands of able bodied young men who are capable and willing to defend their country simply because they are sexual deviates?"348 Another asked in $O N E$ "Why do the Armed Forces reject homosexuals at all? The War Department is surely aware that many capable military men have been and are homosexually inclined." ${ }^{349}$ In reality, the need for manpower became evident during times of armed conflict in the Cold War, Korea and Vietnam, where historian Randy Shilts found that gay purges slowed in times of conflict. From 1950 to 1953, between 400 and 500 sailors were discharged from the Navy each year for homosexuality, but following the Korean War armistice, that number nearly tripled and would remain higher than 1000 every year until the 1960s. In the 1960s, between 1000 and 1500 naval personnel were discharged as undesirable for homosexuality every year, except between 1968 and 1970 where there were only 400 to 600 such discharges, when military deployment to Vietnam was at its highest. ${ }^{350}$

Outside of conflicts, the language of national security remained central to the removal of gay service members. In late 1957, the Office of Naval Intelligence conducted a multi-week surveillance operation in San Diego against retired Rear Admiral Selden Hooper. He had been in the armed forces since 1921 at age seventeen, had commanded a destroyer in World War II, and had been awarded the Silver Star medal. Naval Intelligence observed the retired admiral's relationship with a younger sailor and how they lived together, including their sexual relationship. A few months later, Hooper received a letter from the Navy that he was in violation of UCMJ on the charges of sodomy, conduct that would discredit the armed forces, and "conduct unbecoming to an

\footnotetext{
${ }^{348}$ Fugaté, 42.

349 Robert Gregory, “The Homosexual Draftee," ONE (August 1960), 8.

${ }^{350}$ Shilts, 70. Shilts noted that the Navy appeared to be the only branch of the military that kept such extensive records of anti-gay discharges at this time.
} 
officer and a gentleman. ${ }^{351}$ Hooper's attorney argued that the military had no reason to court martial the retired soldier, but the Navy responded that all retired officers could, in fact, be court martialed as if on active-duty. But, seemingly concerned that Hooper's retirement would present enough of a legal defense, the Navy specifically reinstated Hooper to active service so that he could be court martialed without issue. ${ }^{352}$

Intelligence operations against gay soldiers were extensive and not reserved for just an admiral. Loretta Coller was in the Air Force and described that her mail was often searched by intelligence officers before being questioned about the last time she dated a man or questioned her about her sexual history. She either lied or evaded the questions, but would be called back to answer questions every day. After a month of repeated questioning, the investigators told her about their findings, which included information about her partner's family and even what outfits Coller wore when visiting her. ${ }^{353}$ Coller was offered a general discharge instead of a dishonorable one, and a guarantee she would not face a court martial, if she confessed to her relationship with another woman and named her. She signed a confession, named her girlfriend, and was promptly sent to a court martial anyway. Feeling helpless, "I was like a lamb to slaughter," she recalled. ${ }^{354}$ Naming names was a staple of anti-gay investigations, frequently paired with the least punishing sentence under the UCMJ. Such a practice had led investigators to Hooper too, even though he was retired and married, because a younger gay soldier had been arrested

\footnotetext{
${ }^{351}$ Faderman, 28.

${ }^{352}$ Faderman, 29.

${ }^{353}$ Loretta Coller, in My Country My Right to Serve, 13.

${ }^{354}$ Coller, in My Country My Right to Serve, 15.
} 
in a vice arrest and, like Coller, was likely told to name other gay soldiers for a lighter sentence. ${ }^{355}$

Like government workers in the Red and Lavender Scare, gay service members were described as threats to national security. In Coller's court martial, she had to testify if she thought her homosexuality affected her performance in the Air Force and if she influenced other Air Force members with her homosexuality. Finally, she recalled the question, "Did I realize that I was a security risk being a homosexual?" ${ }^{356}$ Rear Admiral Hooper, despite supportive character witnesses ranging from his mother to the Red Cross, was convicted by court martial, with the approval of the president. The court martial ruled that a retired officer could do nothing considered immoral in private because, "even retired officers form a vital segment of our national defense," and "the salaries they [officers] receive are not solely recompense for past services but ... assure their availability and preparedness in future contingencies. ${ }^{357}$ In this way, no officer could discuss being gay, even when no longer on active service, because they then compromised national security by their very existence. Like Coller and Hooper, Schoen was also dishonorably discharged for his sexuality, entitled to no veteran benefits after nearly two decades of service.

\section{To Be Gay in the Cold War}

The United States moved past the widespread destruction of World War II, only to enter a war of global influence with the Soviet Union, where fighting was done beyond battlefields. Armed with new homes, families, and a larger national security

\footnotetext{
${ }^{355}$ Faderman, 29.

${ }^{356}$ Coller, in My Country My Right to Serve, 15.

${ }^{357}$ Faderman, 30.
} 
infrastructure, Cold War Americans watched their neighbors and colleagues with suspicion in order to find enemies before their influence could grow. Jay Brown was accused of being gay while a soldier but managed to avoid the accusations against him. He was honorably discharged in 1959 , after serving three years, and went to work with the Peace Corps. He went through their training but was suddenly denied admission without explanation. He remembered that his sudden dismissal affected him deeply. "I went into a depression for about six months after that. I couldn't find anything out, they wouldn't tell me who said what, I had no recourse, they just said no and no reason... was ever given." ${ }^{358}$ Years later, he held that his sudden dismissal from the Peace Corps was a direct result of the accusations against him in the military. Against the backdrop of national security rhetoric in the Cold War his sudden blacklisting was not unlike the loss of opportunities, careers, and personal security that faced other gay service members. He, like so many others came to believe that, in order to escape and avoid persecution, the "military encourages gay people to lie and cheat." ${ }^{359}$ His experience further reflects the issues faced by gay Americans in this era. Gay service members left behind the most deadly war in history with a sense of belonging and returned home to take part in an era remembered for its prosperity. Likewise, gay government workers sought stable, wellpaid jobs that would let them contribute to their nation's future as a world leader. But it became clear though the Red and Lavender Scares that, if gay Americans wanted to live in secure homes, they would need to watch out for more than just America's enemies of the Cold War. They were forced hide or be stigmatized in a way that cost their careers

\footnotetext{
${ }^{358}$ Brown, in My Country My Right to Serve, 5. Brown was not alone, as historians like Bérubé, Shilts, and Faderman all described other service members encountering - in one way or another - depression, hopelessness, and even suicide in the wake of similar events.

${ }^{359}$ Brown, in My Country My Right to Serve, 6.
} 
and the security of a stable life. The military and government they had served, which had promised opportunities and benefits for service and sacrifice, compared them to enemies and threats to national security. 


\section{Conclusion}

A short story titled "Courage," by Richard Rand, appeared in the August 1960 issue of $O N E$, "Homosexual Servicemen." 360 In it, a man named Jim is receiving a presidential honor for his service in the Korean War, but has a court date the next day after an anti-gay police sting. Jim feels as if he is living two lives. In one, he is a decorated soldier being honored for his courage in battle. In the other, he is a criminal and those who have arrested him have no idea he was being heralded as heroic. The reality of his double life is that his courageous record could not stop police from turning his life upside-down, and his heroism and medals would matter little when the military learned of his other life. This story, while fictional, mirrored the reality of gay Americans in the culture of the Cold War.

Gay men and women have existed in the United States and in the armed forces much longer than legally and socially permitted. Despite police suppression and public disapproval, twentieth-century Americans their communities visibly grow. By World War II, a cultural shift began within the gay communities of the United States as thousands of gay men and women enlisted in the armed forces. In that shift they met each other, learned about themselves, and created lifelong connections to a new community that would grow after the war. Although military service has long represented a path for the recognition of one's citizenship, this did not apply for gay Americans who were officially limited from military service based on long-standing stereotypes and fears.

Military policies barred gay service members by reinforcing these stereotypes that gay men threatened the wellbeing of other soldiers. Such policies fostered the idea that

${ }^{360}$ Richard Rand, “Courage,” ONE (August 1960), 7. 
only particular kinds of men could adequately serve. Yet the simultaneous entrance of women into the armed forces challenged the traditional idea that the military was a strictly masculine field. At the same time, beliefs pertaining to why women could not participate in military service were often similar to those used to exclude gay men from service. Despite such obstacles, the draft and wartime industry called for millions of recruits and led many Americans, particularly gay men and women, to new economic and social opportunities. Many American minorities saw the opening of military service as a way to advance opportunities for equality and civil rights beyond the war. On military bases across the United States and the globe, gay personnel had new freedoms they did not enjoy at home to learn about their own sexuality and pursue exciting new relationships.

There were two opposing outcomes for the service of returning gay and lesbian veterans. For many hiding their sexuality from public view, they were granted benefits for their service to the country. With the GI Bill, they could retire or have access to education and loans that would start the next chapter in their lives. For others not as lucky, they received nothing and were stripped of their benefits and rank. Military regulations strictly said that gay service members were not to be tolerated in any form. The service of gay soldiers was deemed illegitimate in the eyes of the military, the public, and the VA. The stigma of such dismissals followed them into the civilian world, designating them as "dishonorable" and a detriment to any workplace in American society. This punishing outcome was the case for thousands of gay service members, regardless of rank or achievement, and would serve as military policy for decades after the war. 
Yet with the benefits of the new GI Bill, millions of veterans attended schools and bought homes immediately after the war, and the 1950s marked a new era in the course of the United States. Americans married and families grew to fill new housing developments across the country. There was not an impermeable wall between the lives of heterosexual and homosexual Americans. Gay Americans started homes and careers, some even entered heterosexual marriages due to social pressure. In this prosperity, gay people increasingly sought out each other and magazines for gay audiences like $O N E$ started to circulate across the country. But the Cold War's deep fear of communism and subversives gripped the United States at the highest levels of government and permeated to the rest of society. During the age of McCarthyism and the Red Scare, Americans widely believed that subversive individuals would infect and destroy American society.

$$
\text { Moving Forward }
$$

Senator Joe McCarthy was a major force in American politics between 1950 and his 1954 censure, but the age of McCarthy and the Red Scare had a much longer life. ONE published articles like "You Are A Public Enemy” (1953), “Are Homosexuals Reds?” (1953), “To Be Accused Is To Be Guilty” (1953), and “Are Homosexuals Security Risks?" (1955 and 1960) to address the Red and Lavender Scares throughout the 1950s. By 1964, President Lyndon Johnson's campaign opponent, Senator Barry Goldwater, continued to use the rhetoric of the Lavender Scare as he latched onto the arrest of a White House liaison named Walter Jenkins. Jenkins was arrested in the men's restroom of a YMCA, a known meeting place for gay men. There, like in the 1950s, Republicans like Richard Nixon asserted that gay men were both infiltrators and the 
reason for the "weak" or soft foreign policy of Johnson. ${ }^{361}$ The 1960 s itself saw more major shifts in the American political norm with large social movements like anti-war demonstrations and continued civil rights activism. Within queer communities, new organizations took the lead in activism, and by 1969 the pent-up frustrations of these communities visibly erupted with the Stonewall Riots, firmly starting the gay rights movement.

The expulsion and exclusion of gay service members under the policies of the 1950s continued unabated until the 1990s. In 1991, future president Bill Clinton ran with a campaign promise that he would sign an executive order banning the discrimination of gay and lesbian people in the armed forces, and openly stated for gay and lesbian voters, "I have a vison for the future, and you are a part of it." 362 No previous major presidential candidate had ever been so openly supportive of ending the gay military ban. In response, General Colin Powell threatened to resign if such an executive order were made by President Clinton. Eventually Congress passed a new law in 1993 known as Don’t Ask Don't Tell which, in summary, forbade the military from questioning and barring closeted gay, lesbian, and bisexual service members, but still banned openly LGBT service members. ${ }^{363}$

With Texas v. Lawrence in 2003 and the repeal of Don't Ask Don't Tell in the final days of 2010, the new millennium has seen the decriminalization of homosexuality

\footnotetext{
361 Dean, 220-224.

362 Faderman, 496.

${ }^{363}$ Taylor, 155-159. With the Cold War over, Don't Ask Don't Tell did not rely on the logic of the Lavender Scare that gay people were security risks and instead relied on the older claims that gay military service negatively affected other soldiers. The policy of DADT was based in the belief that the "presence in the armed forces of persons who demonstrate a propensity or intent to engage in homosexual acts would create an unacceptable risk to the high standards of morale, good order and discipline, and unit cohesion that are the essence of military capability." Taylor, 159.
} 
in the United States and the increased equality of military service. The end of Don't Ask Don't Tell did not extend to transgender soldiers, however. The exact number of past and present transgender service members is unknown as it was against military policy to openly be transgender, though researchers have described the number of such active duty soldiers to be in the thousands. ${ }^{364}$ But, in 2016, the Secretary of Defense under President Barrack Obama announced that transgender people would no longer be banned from military service. ${ }^{365}$ The course of transgender military service reversed in 2018 and 2019 following an order by President Donald Trump to remove them from the military. ${ }^{366}$

The experiences of gay men and women in the military, particularly after World War II, were not limited to only their time in service, but frequently extended far into their civilian lives after service. At the same time, the policies that barred them from service and benefits were often reflective of the prejudices and fears of American society. In the words of gay Americans, as long as they showed "true ability" in their lives, their desire was that they "may compete with everyone on equal footing." ${ }^{\prime 367}$ But they faced a long history of legal and social persecution. Although the military appeared promising as a way to be seen as equal American citizens, their service was often deemed illegitimate until recently. Their experiences were of hiding and lying in order to serve and defend

\footnotetext{
${ }^{364}$ M. Jocelyn Elders, George R. Brown, Eli Coleman, Thomas A. Kolditz, and Alan M. Steinman. "Medical Aspects of Transgender Military Service," Armed Force \& Society (2014): 2.

365 Ash Carter, "SECRETARY OF DEFENSE SPEECH: Remarks on Ending the Ban on Transgender Service in the U.S. Military," Department of Defense, (June 30, 2016).

${ }^{366}$ Joshua Block, Chase Strangio, and James Esseks, "Breaking Down Trump's Trans Military Ban," Speak Freely (Blog), ACLU (March 30, 2018). Transgender people are not the only people being newly banned from service by the Trump Administration using rhetoric familiar to the Red and Lavender Scares. In 2017, the Trump Administration put forward a new policy to prevent the service of non-citizen "legal permanent residents" until they "pass" a number of tests that a federal judge described as undefined, arbitrary, and capricious to determine if they are "security risks." Sameer Ahmed and Imaan Patel, "Federal Judge Blocks Trump's Anti-Immigrant Military Enlistment Policy," Speak Freely (Blog), ACLU (November 21, 2018). ${ }^{367}$ Letters to ONE, 25.
} 
their country. By denying LGBTQ+ Americans participation in military service, they were denied veteran benefits for any service they did provide, and denied equal standing as Americans. 


\section{Works Cited}

\section{Primary Sources}

Barbera, Lillian. And So I Joined the Army. Barbera Family Publishing, 1997.

Before Stonewall: The Making of a Gay and Lesbian Community. Directed by Gretta Schiller and Robert Rosenberg. New York, NY: Before Stonewall, Inc., 1985. Digital Film.

Blasius, Mark and Shane Phelan, eds. We Are Everywhere: A Historical Sourcebook of Gay and Lesbian Rights. New York, NY: Routledge, 1997.

Gerber, Henry. Henry Gerber Collection. ONE National Gay \& Lesbian Archives University of Southern California. Los Angeles, CA. Coll2013-034.

Gilgamesh, Joe, Jim Kepner, Michael Lombardi, and Mikhail Itkin. "A search for our roots, 1860-1960," Midwinter Institute panel discussion, Los Angeles, CA. January 1978. ONE National Gay and Lesbian Archives, USC Digital Library. Audio.

Herbert, Esther and Doyle, Marvyl. Esther Herbert and Marvyl Doyle Papers and Photographs. ONE National Gay \& Lesbian Archives, University of Southern California. Los Angeles, CA. Coll2013-030.

Humphrey, Mary Ann. My Country, My Right to Serve: experiences of gay men and women in the military, World War II to the present. New York, NY: Harper Perennial, 1990.

Jones, James. From Here to Eternity. New York, NY: Charles Scribner's Sons, 1951.

Kaes, Anton, Martin Jay, and Edward Dimendberg, eds. The Weimar Republic Sourcebook. Berkley, CA: University of California Press, 1995.

Loftin, Craig M. Letters to ONE: Gay and Lesbian Voices from the 1950s and 1960s. Ithaca, NY: State University of New York Press, 2014.

Lord, James. My Queer War. New York, NY: Farrar, Straus and Giroux, 2011.

Roosevelt, Franklin "Franklin Roosevelt's Statement on Signing the G.I. Bill. June 22, 1944." Franklin D. Roosevelt Presidential Library and Museum. (Accessed January 25, 2019.) http://docs.fdrlibrary.marist.edu/odgist.html

Schaffner, Bertram. Interview 41773. Visual History Archive, USC Shoah Foundation, 1998. (Accessed December 30, 2018)

\section{Cited Magazine Articles from Archives}

Block, Martin, Dale Jennings, and Don Slater (eds.) "Your Rights In Case of Arrest." ONE. March 1953. ONE National Gay \& Lesbian Archives, USC Digital Library, University of Southern California. Los Angeles, CA. Coll2011-001.

Fugaté, James. "Under Honorable Conditions." Mattachine Review. May-June 1955. San Francisco Bay Area Gay and Lesbian Serials, Berkeley Library, University of California, Berkeley. Berkeley, CA. Digital. (Accessed April 1, 2019 via Digital Assets) http://digitalassets.lib.berkeley.edu/sfbagals/Mattachine_Review/1955_Mattachin e_May-Jun.pdf

Galbraith, A. E. "Die Insel." ONE. January 1953. ONE National Gay \& Lesbian Archives, USC Digital Library, University of Southern California. Los Angeles, CA. Coll2011-001. 
Gerber, Henry. "The Society for Human Rights." ONE. September 1962. ONE National Gay \& Lesbian Archives, USC Digital Library, University of Southern California. Los Angeles, CA. Coll2011-001.

Gregory, Robert. "The Homosexual Draftee." ONE. August 1960. ONE National Gay \& Lesbian Archives, USC Digital Library, University of Southern California. Los Angeles, CA. Coll2011-001.

Jennings, Dale. "To Be Accused, Is to be Guilty." ONE. January 1953. ONE National Gay \& Lesbian Archives, USC Digital Library, University of Southern California. Los Angeles, CA. Coll2011-001.

Jennings, Dale (ed.) "ONE is not grateful." ONE. October 1953. ONE National Gay \& Lesbian Archives, USC Digital Library, University of Southern California. Los Angeles, CA. Coll2011-001.

Lalo, Elizabeth. "Must I Answer That Cop?" ONE. October 1953. ONE National Gay \& Lesbian Archives, USC Digital Library, University of Southern California. Los Angeles, CA. Coll2011-001.

Laporte, Rita. "Living Propaganda." The Ladder. June 1965. San Francisco Bay Area Gay and Lesbian Serials, Berkeley Library, University of California, Berkeley. Berkeley, CA. (Accessed April 1, 2019 via Digital Assets) http://digitalassets.lib.berkeley.edu/sfbagals/The_Ladder/1965_Ladder_Vol09_N o09_Jun.pdf

Mcintire, Dal. "Tangents: news and views.” ONE. November, 1960. ONE National Gay \& Lesbian Archives, USC Digital Library, University of Southern California. Los Angeles, CA. Coll2011-001.

Miss E.M. "To Be Accused Is To Be Guilty: 2. The Ever-Present Past." ONE. April 1953. ONE National Gay \& Lesbian Archives, USC Digital Library, University of Southern California. Los Angeles, CA. Coll2011-001.

ONE's Legal Counsel. "The Law of Mailable Material." ONE. October 1954. ONE National Gay \& Lesbian Archives, USC Digital Library, University of Southern California. Los Angeles, CA. Coll2011-001.

P., J. "For Men Only?" ONE. August 1953. ONE National Gay \& Lesbian Archives, USC Digital Library, University of Southern California. Los Angeles, CA. Coll2011-001.

Rand, Richard. "Courage." ONE. August 1960. ONE National Gay \& Lesbian Archives, USC Digital Library, University of Southern California. Los Angeles, CA. Coll2011-001.

Reid, Ann Carll (ed.) "Where You Can Buy ONE." ONE. January 1955. ONE National Gay \& Lesbian Archives, USC Digital Library, University of Southern California. Los Angeles, CA. Coll2011-001.

\section{Secondary Sources}

Ahmed, Sameer and Imaan Patel, "Federal Judge Blocks Trump's Anti-Immigrant Military Enlistment Policy," Speak Freely (Blog), ACLU, November 21, 2018. (Accessed April 1, 2019) https://www.aclu.org/blog/immigrants-rights/federaljudge-blocks-trumps-anti-immigrant-military-enlistment-policy 
Ball State University, "The Army Specialized Training Program," Bracken Library Stoeckel Archives of Local History. (Accessed November 1, 2018 via Special Collections)

Bayley, Erwin R. Joe McCarthy and the Press. Madison, WI: The University of Wisconsin Press, 1981.

Belkin, Aaron. Bring Me Men: military masculinity and the benign façade of American empire 1898-2001. New York, NY: Columbia University Press, 2012.

Belmonte, Laura A. Selling the American Way: U.S. Propaganda and the Cold War. Philadelphia, PA: University of Pennsylvania Press, 2008.

Bérubé, Allan and D'Emilio, John. "The Military and Lesbians during the McCarthy Years," Signs 9:4 (Summer 1984): 759-775

Bérubé, Allan. Coming Out Under Fire: the history of gay men and women in World War Two. Chapel Hill, NC: The University of North Carolina Press, 2010. $20^{\text {th }}$ Anniversary Edition.

Block, Joshua, Chase Strangio, and James Esseks. "Breaking Down Trump's Trans Military Ban.” Speak Freely (Blog), ACLU. March 30, 2018. (Accessed April 1, 2019) https://www.aclu.org/blog/lgbt-rights/transgender-rights/breaking-downtrumps-trans-military-ban

Borch III, Fred L. "The History of "Don't Ask Don't Tell" in the Army." Military Law Review 203 (2010): 189-206.

Boston College, "Jesuit History at BC," Office of the University Historian. (Accessed November 1, 2018) https://www.bc.edu/offices/historian/resources/jesuit.html

Breen, Susan Cousins. "Beyond the Emotional Turmoil: Gay Psychiatrist Bertram Schaffner '32 Brings Compassion and Dignity to His Homosexual Patients," Swarthmore College Bulletin (Blog), Swarthmore College, October 2009. (Accessed April 1, 2019) https://bulletin.swarthmore.edu/bulletin-issuearchive/archive $\mathrm{p}=310 . \mathrm{html}$

Bronski, Michael. A Queer History of the United States. Boston, MA: Beacon Press, 2011.

Canaday, Margot. The Straight State: Sexuality and Citizenship in Twentieth-century America. Princeton, NJ: Princeton University Press, 2011.

Carter, Ash. "SECRETARY OF DEFENSE SPEECH: Remarks on Ending the Ban on Transgender Service in the U.S. Military." Department of Defense. June 30, 2016. (Accessed April 1, 2019) https://dod.defense.gov/News/Speeches/SpeechView/Article/821833/remarks-on-ending-the-ban-on-transgender-service-in-theus-military/

Corber, Robert J. Cold War Femme: Lesbianism, National Identity, and Hollywood Cinema. Durham, NC: Duke University Press, 2011.

Corber, Robert J. Homosexuality in Cold War America: Resistance and the Crisis of Masculinity. Durham, NC: Duke University Press, 1997.

Chauncey, George. Gay New York: Gender, Urban Culture, and the Making of the Gay Male World 1890-1940). New York, NY: Basic Books, 1994.

Cuordileone, K.A. Manhood and the American Political Culture in the Cold War. New York, NY: Routledge, 2005. 
De Hart, Jane Sherron. "Containment at Home: Gender, Sexuality, and National Identity in Cold War America," in Rethinking Cold War Culture, ed. Peter J. Kuznik and James Gilbert. Washington, DC: Smithsonian Books, 2010: 124-155.

De la Croix, St. Sukie. Chicago Whispers: a history of LGBT Chicago before Stonewall. Madison, WI: University of Wisconsin Press, 2012.

Dean, Robert D. Imperial Brotherhood: Gender and the Making of Cold War Foreign Policy. Amherst, MA: University of Massachusetts Press, 2001.

Dickson, Paul and Allen, Thomas B. The Bonus Army: An American Epic. New York, NY: Walker \& Company, 2004.

Elders, M. Jocelyn, George R. Brown, Eli Coleman, Thomas A. Kolditz, and Alan M. Steinman. "Medical Aspects of Transgender Military Service," Armed Force \& Society (2014): 1-22.

Estes, Steve. I am a Man!: Race, Manhood, and the Civil Rights Movement. Chapel Hill NC: The University of North Carolina Press, 2005.

Faderman, Lillian. The Gay Revolution: The story of the struggle. New York, NY: Simon and Schuster Paperbacks, 2015.

Filene, Peter. "“Cold War Culture' Doesn't Say It All," in Rethinking Cold War Culture, ed. Peter J. Kuznik and James Gilbert. Washington, DC: Smithsonian Books, 2010: 156-174.

Fried, Richard M. Nightmare in Red: The McCarthy Era in Perspective. New York, NY: Oxford University Press, 1990.

Friedman, Andrea. Citizenship in Cold War America: the National Security State and the Possibilities of Dissent. Amherst, MA: University of Massachusetts Press, 2014.

Gallo, Marcia M. Different Dauthers: A History of the Daughters of Bilitis and the Rise of the Lesbian Rights Movement. Emeryville, CA: Seal Press, 2007.

Hamph, M. Michaela. "'Dykes' or 'Whores': Sexuality and the Women's Army Corps in the United States during World War II," Women's Studies International Forum 27 (2004): 13-30.

Hamph, M. Michaela. Release a Man for Combat: The Women's Army Corps During World War II. Cologne, Germany: Böhlau Verlag, 2010.

Jackson, Paul. One of the Boys: Homosexuality in the Military during World War II. Montreal, Quebec and Kingston, Ontario: McGill-Queen's University Press, 2010. Second Edition.

Jarvis, Christina S. The Male Body at War: American masculinity during World War II. DeKalb, IL: Northern Illinois University Press, 2004.

Johnson, David K. The Lavender Scare: the Cold War persecution of gays and lesbians in the federal government. Chicago, IL: University of Chicago Press, 2004.

Jones, Kaylie. "Kaylie Jones : My Father, James Jones, and Censorship" Huffington Post, April 10, 2011. (Accessed January 1, 2019) https://www.huffpost.com/entry/myfather-james-jones-and_b_847145?utm_hp_ref=censorship

Kaiser, Charles. The Gay Metropolis. New York, NY: Grove Press, 1997.

Kindsvatter, Peter S. American Soldiers: Ground Combat in the World Wars, Korea, \& Vietnam. Lawrence, KS: The University Press of Kansas, 2003.

Langham, Jeffery. "Remembering Gay Pioneer Bertram Schaffner," Through Testimony (Blog), USC Shoah Foundation, June 7, 2016. (Accessed April 1, 2019) 
https://sfi.usc.edu/blog/jeffrey-langham/remembering-gay-pioneer-bertramschaffner

Latham, Michael E. Modernization as Ideology. Chapel Hill, NC: University of North Carolina Press, 2000.

Lewis, Carolyn Herbst. Prescription for Heterosexuality: Sexual Citizenship in the Cold War Era. Chapel Hill, NC: University of North Carolina Press, 2010.

Loftin, Craig M. Masked Voices: gay men and lesbians in Cold War America. Albany, NY: State University of New York Press, 2012.

Markusen, Ann. "Cold War Workers, Cold War Communities," in Rethinking Cold War Culture, ed. Peter J. Kuznik and James Gilbert. Washington, DC: Smithsonian Books, 2010: 35-60.

May, Elaine Tyler. Homeward Bound: American families in the Cold War era. New York, NY: Basic Books, 2017. Revised, $4^{\text {th }}$ Edition

Meyer, Leisa D. Creating GI Jane: Sexuality and Power in the Women's Army Corps During World War II. New York, NY: Columbia University Press, 1996.

Meyerowitz, Joanne. "Sex, Gender, and the Cold War Language of Reform," in Rethinking Cold War Culture, ed. Peter J. Kuznik and James Gilbert. Washington, DC: Smithsonian Books, 2010: 106-123

Rivers, Daniel Winunwe. Radical Relations: Lesbian Mothers, Gay Fathers, \& Their Children in the United States since World War II. Chapel Hill, NC: The University of North Carolina Press, 2013.

Rotundo, E. Anthony. American Manhood: Transformations in Masculinity from the Revolution to the Modern Era. New York, NY: BasicBooks, 2001.

Saldin, Robert P. "Strange Bedfellows: War and Minority Rights," World Affairs 173:6 (2011): 57-66.

Salyer, Lucy E. "Baptism by Fire: Race, Military Service, and U.S. Citizenship Policy, 1918-1935," Journal of American History 91:3 (2004): 847-876.

Sanchez, George. "'What's Good for Boyle Heights Is Good for the Jews': Creating Multiracialism on the Eastside during the 1950s." American Quarterly 56:3 (2004): 633-661.

Schrecker, Ellen. Many are the Crimes: McCarthyism in America. Boston, MA: Little, Brown and Company, 1998.

Senelick, Laurence. "The Homosexual Theatre Movement in the Weimar Republic," Theatre Survey 49:1 (2008): 5-35.

Sears, James T. Behind the Mask of the Mattachine: The Hal Call Chronicles and the Early Movement for Homosexual Emancipation. New York, NY: Routledge, 2011.

Shilts, Randy. Conduct Unbecoming: Gay and Lesbians in the U.S. Military. New York, NY: St. Martin's Press, 1994.

Sides, Josh. "Straight into Compton: American Dreams, Urban Nightmares, and the Metamorphosis of a Black Suburb," American Quarterly 56:3 (2004): 583-605.

Takaki, Ronald. A Different Mirror: A History of Multicultural America (New York, NY: Bay Back Books, 2008). Revised Edition.

Takaki, Ronald. Double Victory: A Multicultural History of America in World War II (New York, NY: Bay Back Books, 2000). 
Taylor, William A. Military Service and American Democracy: From World War II to the Iraq and Afghanistan Wars. Lawrence, KS: University Press of Kansas, 2016.

U.S. Department of Veterans Affairs. "About GI Bill: History and Timeline." VA

Education and Training. (Accessed January 20, 2019) https://www.benefits.va.gov/gibill/history.asp

Wake, Naoko. "The Military, Psychiatry, and "Unfit" Soldiers, 1939-1942." Journal of the History of Medicine and Allied Sciences 62:4 (2007): 461-494.

Wertheim, Albert. "The McCarthy Era and the American Theatre." Theatre Journal 34:2 (May 1982): 211-222.

Whitfield, Stephen J. The Culture of the Cold War. Baltimore, MD: The Johns Hopkins University Press, 1996. Second Edition. 